\title{
VAGRANCY-TYPE LAW AND ITS ADMINISTRATION *
}

Caleb Foote $\dagger$

\section{INTRODUCTION}

This study combines analysis of the history, theory and purposes of vagrancy-type laws with a report of their administration by the police, magistrates and correctional authorities in Philadelphia. Such a dual approach is essential. Minor offenses are seldom reviewed by higher courts, and the actual limits of vagrancy are set not in the statute but by practices of police and magistrates. Conversely, an intelligent appraisal of these practices requires some historical orientation. The vagrancy laws " . . . might be unintelligible if we did not regard them as a supplement to the old Poor Laws . . ."; they continue to reflect their inception in the fourteenth century when they were "a kind of substitute for the system of villainage and serfdom." 2

The material on the administration of vagrancy-type laws was obtained by a field study of Philadelphia practices. The basic technique employed was the intermittent observation of hundreds of trials in the magistrates' courts during a period beginning in 1951, supplemented by interviews with a small sample of convicted vagrants at the House of Correction and the compilation of statistical information from police and House of Correction records. This method was time-consuming and in many ways unsatisfactory, but there was no alternative, for no stenographic notes of testimony are made at the trials, and the records maintained by the magistrates were useless for the purpose of this study.

It is impossible, short of a more intensive examination, to determine whether the hundreds of vagrancy, drunkenness and disorderly conduct trials which were observed were exceptional or whether they represent a fair sample of Philadelphia practices. It is believed, however, that the sample is representative. A number of different magis-

* This study was financed by a grant from the Thomas Skelton Harrison Foundation, an agency created by the will of Thomas Skelton Harrison to promote good government in Philadelphia.

$\dagger$ Associate Professor of Law, University of Nebraska. A.B., 1939, Harvard University; M.A., 1941, Columbia University; LL.B., 1953, University of Pennsylvania.

1. Kenny, Outlines of THE CRIminal Law 381 (15th ed. 1936).

2. 3 Stephen, History of the Criminal Law of England 204 (1883). 
trates conducted the hearings, and while there were differences among them, their general attitude towards and conduct of vagrancy-type cases was remarkably similar. The fact that the observation extended from June, 1951, through March, 1954, and that the more serious abuses in magisterial practice so pervaded all of the observed hearings throughout this period make it reasonable to infer that they are typical of Philadelphia practices.

While the administrative material is drawn solely from Philadelphia, the significance of the study has broader application. No comparable study has been made elsewhere, but it is probable that many Philadelphia practices are widespread.

At a time when there is dispute as to the extent to which latitude should be accorded police and administrative action by easing the procedural and constitutional restrictions imposed by our criminal law, ${ }^{3}$ the practices described in this study offer a revealing illustration of what happens when those restrictions are removed. Procedural due process does not penetrate to the world inhabitated by the "bums" of Philadelphia, and this description of what occurs in that world is certainly relevant to the problem of how far our criminal law administration should relax constitutional and procedural controls to permit greater administrative police discretion.

\section{A Vagrant's Day in Court}

Because the issues raised by vagrancy-type law can only be understood in the context of the law's everyday administration, examples of typical proceedings in the Philadelphia magistrates' courts are a useful introduction to the problem. The enforcement efforts of the police and magistrates were conducted on a year-round basis, but from time to time during the period of this study the tempo of enforcement was stepped up with a well-publicized "drive" against vagrants. One of the more recent examples was a "cleanup" to make the newly completed Independence Mall "out of bounds for undesirables," " the theory apparently being that the publicity would induce vagrants already in the city to depart and would deter "undesirables" who had planned to come to Philadelphia from entering the city. A description of one of these "cleanups" reveals many of the complex factors and motives that underlie vagrancy administration.

On January 31, 1954, the Philadelphia press reported that police had “. . . opened a drive against vagrants and habitual drunkards

3. See, e.g., the differences of opinion within the Supreme Court on two recently decided cases: Stein v. New York, 346 U.S. 156 (1953); Irvine v. California, 347 U.S. 128 (1954).

4. Philadelphia Inquirer, Aug. 9, 1955, p. 1, col. 1. 
in the central city area." By February 2, the drive was at its height, and that morning 56 cases were awaiting disposition when the magistrate opened the daily divisional police court for the district which included the "skid row" and the central city area. These cases were the last items on the morning's docket, and the magistrate did not reach them until 11:04 a.m. In one of the cases there was a private prosecutor, and the hearing of evidence consumed five minutes. As court adjourned at $11: 24$, this left 15 minutes in which to hear the remaining 55 cases. During that time the magistrate discharged 40 defendants and found 15 guilty and sentenced them to three month terms in the House of Correction.

Four of these committed defendants were tried, found guilty and sentenced in the elapsed time of seventeen seconds from the time that the first man's name was called by the magistrate through the pronouncing of sentence upon the fourth defendant. In each of these cases the magistrate merely read off the name of the defendant, took one look at him and said, "Three months in the House of Correction." As the third man was being led out he objected, stating, "But I'm working . . .," to which the magistrate replied, "Aw, go on."

The magistrate then called the name of one defendant several times and got no answer. Finally he said, "Where are you, Martin?" The defendant raised his hand and answered, "Right here." "You aren't going to be 'right here' for long," the magistrate said. "Three months in Correction." Another defendant was called. The magistrate stated: "I'm going to send you up for a medical examination-three months in the House of Correction."

A number of defendants were discharged with orders to get out of Philadelphia or to get out of the particular section of Philadelphia where they were arrested. "What are you doing in Philadelphia?" the magistrate asked one of these. "Just passing through." "You get back to Norristown. We've got enough bums here without you." Another defendant whose defense was that he was passing through town added, "I was in the bus station when they arrested me." "Let me see your bus ticket," the magistrate said. "The only thing that's going to save you this morning is if you have that bus ticket. Otherwise you're going to Correction for sure." After considerable fumbling the defendant produced a Philadelphia to New York ticket. "You better get on that bus quick," said the magistrate, "because if you're picked up between here and the bus station, you're a dead duck."

In discharging defendants with out-of-the-central-city addresses, the magistrate made comments such as the following: 


\section{"You stay out in West Philadelphia."}

"Stay up in the fifteenth ward; I'll take care of you up there."

"What are you doing in this part of town? You stay where you belong; we've got enough bums down here without you."

Near the end of the line the magistrate called a name, and after taking a quick look said, "You're too clean to be here. You're discharged."

The next morning, the Philadelphia Inquirer ran an editorial under the title, "Get Bums off the Street and Into Prison Cells," 5 which noted with satisfaction that three month sentences were being imposed and that ". . . Chief Magistrate Clothier has threatened them with jail sentences of two years." The editorial felt that "If they have nothing worse to expect from the police than a warm cell to sleep it off for the night, the vagrants will hardly be discouraged. But two years in prison is something else again; only the most hardened bum will take a chance on that." The editorial had no suggestions on how one who was already a "bum" could avoid taking the chance.

The hearings that morning moved even more rapidly; between 50 and 60 defendants were handled between $10: 39$ and 10:54. Five defendants were committed under the same procedure already noted, the magistrate merely calling their names, taking one look, and then pronouncing sentence. To another he said, "You look like one, three months."

"Three months for you, Tom Harris," he said to a defendant. "I'm working," the defendant replied. "Yes, I know," the magistrate responded, "working on the Bible. Take him away, oh, and take $\mathrm{Mr}$. Gurdy here back with you for another three months."

Three other defendants alleged the defense of working. Two were ignored, but the third kept insisting that he had a job with a packing company. The magistrate asked him under whom he worked, what the first name of his boss was, and finally discharged him.

"Well, what do you want to tell me?" the magistrate said to another defendant. The reply was that he was on his way to Harrisburg. "You keep going to Harrisburg, then, and don't you stop, because if you do, you're a dead duck." Other defendants from Camden and Conshohocken were told to "go back where you belong."

The court room at the 12 th and Pine St. police station was jammed at these hearings. Spectators were packed in solidly behind the railing, and the defendants, all of whom were herded out at once,

5. Id., Feb. 3, 1954, p. 30, cols. 1 \& 2. 
occupied every bit of space between the rail and the bench. The noise and confusion were continuous.

At one of the hearings floodlights were mounted behind the bench and as the defendants were called up one by one, a photographer, crouching just behind the magistrate, took motion pictures of the proceedings. The lights were arranged in such a way that they must have blinded those standing in front of the magistrate; the effect was much like that of a police line-up. ${ }^{6}$

Although the legal effect of "discharged" is that the defendant has been found not guilty and is free to go, this was not the usual result at these hearings. As the "discharged" defendant made his way out of the crowded courtroom, he had to pass an officer who directed him either to the left, which led to the hallway and the street, or to the right, back to the cell block. Most of the acquitted were directed to the right; only those who looked "clean" or were better dressed or obviously physically incapable of any work were freed at once. Some of those sent back to cells objected, but the officer would state: "Oh, go on, some work will do you good." The detained men, whom both police and magistrates called the "goon squad," were kept for a couple of hours to mop and clean the building.

As the hearings progressed through February the court adopted a new technique which governed assignments to the "goon squad." Each defendant was asked how much he had to contribute to the magistrate's "favorite charity." Those who dropped at least a dollar into a collection box for the Heart Fund, which was on the desk, were freed at once. Those who contributed something more than $25 \%$ were also usually exonerated. Those who were discharged but did not contribute anything or enough were assigned to the squad.

This 1954 winter drive lasted for almost a month. Usually the duration was shorter, and as soon as the newspaper publicity ceased, the atmosphere at the hearings relaxed. With no drive in progress, there were fewer spectators, a higher proportion of discharges, and the magistrates sometimes took longer to hear the cases.

Hearings observed earlier at another court before other magistrates are illustrative of the unpublicized enforcement which went on between drives. At the time the court was observed, it was handling up to 1600 summary cases a month, and of necessity it worked rapidly.

6. Compare this practice with the American Bar Association's Judicial Canon 35, as amended Sept. 15, 1952, 77 A.B.A. REP. 110 (1952), and as adopted by the Pennsylvania Bar Association, which bans such photography because it is ". . . calculated to detract from the essential dignity of the proceedings, distract the witness in giving his testimony, degrade the court, and create misconceptions with respect thereto in the mind of the public...." (Italics omitted.) 
One of the magistrates did not even bother to hear the routine drunkenness cases; only aggravated offenders whom the police wished to have committed were brought before him, and the other defendants were automatically discharged without a hearing. The usual practice, however, was for the magistrate to tell an officer, "bring on the boarders," and for the police to herd all the vagrancy-type defendants into the courtroom at one time, a process that was frequently accompanied by general hilarity. The magistrate greeted his favorites with a broad grin; the police joked with the defendants as they shoved them along; and the loafers on the spectator's side of the railing joked about the stench. The officer who sat with the magistrate took the night list of arrests and called the defendants one by one. Some were still so drunk that they could scarcely make it across the room alone, and stood stolidly, with glazed eyes. The emaciated, gaunt, tattered appearance of some indicated both poverty and chronic alcoholism. Many of the defendants were discharged with a brief explanation:

"George, I feel sorry for you; go on home and quit drinking:" "I haven't seen you for three weeks-discharged."

"You work, don't you? I know you. I know every one of you. I'm around here seven days a week, 365 days a year. Now go on and get back to work."

But there were some of the same summary convictions noted above, where as soon as a defendant's name was called, and while he was still making his way forward, the magistrate pronounced: "Three months in the House of Correction," and the police hustled the convicted man back to his cell. Presumably in these cases, listed as "drunk" on the arrest roster but as habitual drunkenness on the commitment sheet, the test of habitualness being applied was that described by several magistrates as: "When you get sick of seeing their faces, you send them to Correction."

Most of the Philadelphians were discharged, but one defendant who gave a Philadelphia address was next asked, "Do you have any proof that you live there?" "No, judge, I don't have anything with me." "Three months in the House of Correction." As another Philadelphian, summarily given the same sentence, was led away, the magistrate remarked to one of the officers, "He doesn't belong in this district. He ought to stay where he belongs."

Different magistrates followed different policies regarding outof-town transients. Some followed the practice of discharging outof-town defendants with a warning to leave Philadelphia immediately. Another magistrate's invariable opening gambit was the question, 
"Where do you live?" If the answer was anything other than a Philadelphia address, usually a three months sentence was immediately imposed.

\section{Punishment by Analogy}

Enough has been said to indicate the speed and informality characteristic of Philadelphia's vagrancy-type proceedings. Any legal analysis of such cases is handicapped at the outset by the difficulty of determining what law was being applied by a magistrate in any given case. The crimes which form the components of vagrancy-type legislation and which were available to the magistrates as sanctions in these cases involved the following statutes.

\section{Vagrancy}

At common law a vagrant is an idle person who is without visible means of support and who, although able to work, refuses to do so. The offense is punishable in all American jurisdictions, ${ }^{7}$ with many variations from and accretions upon the common-law concept. The Pennsylvania vagrancy statute ${ }^{8}$ defines as vagrants persons who come from outside the state, follow no labor, are without visible means of support, and are unable to give a ". . . reasonable account of themselves or their business in such place." A vagrant can be tried summarily, i.e., without the necessity for indictment or the right to a jury trial; in Pennsylvania he can be punished with imprisonment up to six months for the first offense and up to two years for certain subsequent offenses. ${ }^{9}$

\section{Habitual Drunkenness}

This offense, sometimes called "common drunkenness," is punishable in many jurisdictions, frequently as a part of a broad vagrancy statute. $^{10}$ It must be distinguished from occasional acts of intoxication, for defendants are punishable only if subject to a fixed habit of drunkenness, such as that of one who is drunk "one-half of his time."11

7. By statute in all states except West Virginia, where it is a common-law crime. City of Huntington v. Salyer, 135 W.Va. 397, 63 S.E.2d 575 (1951); see Ex parte Hudgins, 86 W.Va. 526, 103 S.E. 327 (1920).

8. PA. Star. Ans. tit. 18, $\S 2032$ (Purdon 1945 ). The penalty provided by this act is not less than 30 days or more than 6 months. Id. $\S 2033$.

9. By the House of Correction Act, imprisonment of up to 1 year for a first offender and 2 years for repeaters is provided. Id. tit. 61, $\$ \$ 672,681$ (Purdon 1930). See also the statute proscribing the offense of tramping. Id. tit. 18, $\$ 4617$ (Purdon 1945); no use of this statute was observed during this study.

10. E.g., Ala. CODE ANn. tit. 14, $\$ 437$ (1940).

11. Ludwick v. Commonwealth, $18 \mathrm{~Pa}$. 172, 175 (1851); see Commonwealth v. Whitney, 71 Mass. (5 Gray) 85 (1855) (reversing conviction for being a common drunkard where proof showed only three instances of intoxication within six months). 
The Pennsylvania law on this point is ambiguous, and under very questionable authority, Philadelphia police and magisterial practice assumes that habitual drunkenness is a crime subject to the same penalty as vagrancy. Pennsylvania explicitly makes criminal only the lesser offense of intoxication, which proscribes a single act of drunkenness and which is punishable by a fine of either $67 \phi^{12}$ or $\$ 5,,^{13}$ but not by imprisonment. The only authority for imposing prison sentences for drunkenness is found in the statute establishing the House of Correction, which provides that the institution shall be the place of imprisonment for "all persons, adults or minors, that may hereafter be convicted, according to the laws of this commonwealth . . . as a vagrant, drunkard, or disorderly streetwalker." 14 This statute is merely concerned with the treatment of offenders convicted under other laws and does not purport to create the crime of being a "drunkard."

\section{Disorderly Conduct}

The Pennsylvania statute is typical: "Whoever wilfully makes or causes to be made any loud, boisterous and unseemly noise or disturbance to the annoyance of the peaceable residents nearby, or near to any public highway [or other public place], whereby the public peace is broken or disturbed or the traveling public annoyed . . ." is guilty of disorderly conduct and is punishable upon conviction in a summary proceeding with a fine not exceeding $\$ 10$, or, in default of payment of the fine, with imprisonment not exceeding thirty days. ${ }^{15}$

Pennsylvania also has a pickpocket statute, ${ }^{16}$ which could be used against vagrancy-type defendants, but no prosecutions under this statute were observed. The state has not enacted a "public enemy" law proscribing the association of known criminals for an unlawful purpose. ${ }^{17}$ Thus vagrancy, habitual drunkenness and, to a lesser extent, disorderly

12. Pa. Stat. Ann. tit. 18, $\$ 1523$ (Purdon 1945).

13. Id. tit. 47, $\$ 722$ (Purdon 1952).

14. The basis of the practice is the House of Correction Act. Id. tit. 61, $\S \S 672$, 681 (Purdon 1930). The only authority for punishing anyone as an habitual drunkard, therefore, would be under the statute preserving common-law offenses, id. tit. $18, \S 5101$ (Purdon 1945), which would apply if habitual drunkenness were an offense at common law. This question has never been decided by Pennsylvania courts, but other jurisdictions have held that it is not. Commonwealth v. O'Connor, 89 Mass. (7 Allen) 583 (1863) ; State v. Munger, 43 Wyo. 404, 4 P.2d 1094 (1931); see State v. Hunter, 106 N.C. 796, 11 S.E. 366 (1890); see also 2 Broom And Hadley, Commentaries 446 (Wait ed. 1875) (intoxication not an indictable offense at common law, although common drunkenness sometimes treated as a public nuisance).

15. PA. Stat. Ann. tit. 18, $\$ 4406$ (Purdon 1945).

16. $I d . \S 4821$, providing a punishment of not more than 90 days or a peace bond for not more than one year.

17. E.g., N.J. STAT. ANn. §2A:170-1 (1953). 
conduct were the important working tools of the police in the cases observed.

Even within these narrow confines, however, it was not easy to determine which statute was being applied in any given case. The police roster of arrests, which the magistrates used as a docket, listed the charge entered by the arresting officer and also provided a space for the officer to note whether the arrestee was drunk or sober on arrest. In no observed hearing, however, was this charge read to the defendant. Occasionally it was clear that the magistrate was proceeding against a defendant as an habitual drunkard, as where the testimony indicated that he was a repeated offender and no issue of transient status was involved. Sometimes when imposing sentence, the magistrate for the first time would tell the defendant the crime with which he was charged. An example was a case where the police charge was "drunk" and where the trial of the defendant consisted of the following exchange:

Magistrate: "Where do you live?"

Defendant: "Norfolk."

Magistrate: "What are you doing in Philadelphia?"

Defendant: "Well, I didn't have any work down there, so I came up here to see if I could find

Magistrate (who had been shaking his head): "That story's not good enough for me. I'm going to have you investigated. You're a vagrant. Three months in the House of Correction.";

During one month in one police district there were 1125 arrests for summary offenses; 139 of these defendants were sentenced to three months, and five were sentenced to six months. Of these commitments, the police arrest records charged 57 with "habitual drunk," 50 with "drunk," 27 with "vagrancy," five with "drunk and vagrant," two with "drunk and panhandling," two with "disorderly conduct," and one with "drunk and disorderly." Most of these cases were observed, and in many of them it was impossible to determine what crime the magistrate had in mind when the sentence was imposed. Some of those arrested merely as "drunk" were habitual offenders, and some charged with "habitual drunk" had apparently never been in Philadelphia before and therefore could not have been known to the police as habitual anythings. A number of those listed as "drunk" and committed as "habitual drunk" were apparently being punished for something unrelated to their intoxication, the magistrate imposing sentence because the defendant was not "where you belong." 
Where conviction can be obtained by sight and smell alone, it makes little practical difference what charge is listed in the records, and it was apparent that police and magistrates frequently used these offenses interchangeably. The definition of vagrancy and the fact of drunkenness are regarded as merely illustrative of a mode of life which is to be suppressed. The vagrancy statute describes what is commonly known as a "bum"; so, by analogy, any bum is punishable, whether or not his acts amount to the legal definition of vagrancy or habitual drunkenness. Add to this the fact that most "vagrants" also appeared to be chronic alcoholics and that most alcoholics meet the generous magisterial definition of vagrancy, and the compounding and confusion of the statutes is understandable.

Such loose administration was not restricted by the technical elements of a crime. Conviction as an habitual drunkard required no proof beyond simple intoxication. Many Philadelphia residents were committed as vagrants under a statute limiting that crime to non-residents who have come "from without the Commonwealth." Many out-of-state vagrancy defendants were not allowed to give an explanation of their presence in Philadelphia, although the statute provides that it shall be a defense. These problems of proof will be considered in more detail below.

Such administration explains two curious anomalies found in police and prison records. One is the fact that in 1950 in Philadelphia there were 1430 commitments of vagrants to the House of Correction, but only 1241 arrests for that offense. ${ }^{18}$ As a number of those arrested for vagrancy were discharged-over 40 per cent by one sample tabulation ${ }^{19}$ - the discrepancy is substantial. The excess of convictions over arrests doubtless resulted from the method of recruiting the ranks of vagrants in part from those arrested and brought before the magistrates merely as drunks. Second, the records of habitual offenders at the House of Correction frequently showed vagrancy convictions interspersed among commitments as habitual drunkards, which under the Pennsylvania law would be legally impossible. This interchangeable use of the two offenses is illustrated by the record of an inmate interviewed in the summer of 1951 :

18. Phila. House of Correction, Ann. Rep. 42 (1950); Phila. Bureau of Police, Ann. Rer. table 1 (1950).

19. Philadelphia 6th Police District, June 1951. Arrests for vagrancy, 46, of whom 20 discharged and 26 committed. Arrests for "drunk and vagrant," 7 , of whom 2 discharged and 5 committed. But for drunkenness the proportion of discharges was very high. There were 850 arrests for "drunkenness," of whom 51 were committed; 89 arrests for "habitual drunkenness," of whom 57 were committed; thus a total of 108 out of 939 drunkenness arrests were committed. 


$\begin{array}{rlrr}\text { Committed } & \text { Charge } & \text { Sentence } & \text { Discharged } \\ 6 / 4 / 47 & \text { Vagrancy } & 6 \text { months } & 12 / 4 / 47 \\ 12 / 22 / 47 & \text { Vagrancy } & 3 \text { months } & 3 / 9 / 48 \\ 4 / 9 / 48 & \text { Vagrancy } & 3 \text { months } & 6 / 25 / 48 \\ 8 / 7 / 49 & \text { Hab. Drunk. } & 3 \text { months } & 10 / 25 / 49 \\ 10 / 31 / 49 & \text { Hab. Drunk. } & 3 \text { months } & 12 / 30 / 49 \\ 1 / 4 / 50 & \text { Vagrancy } & 3 \text { months } & 3 / 22 / 50 \\ 3 / 25 / 50 & \text { Hab. Drunk. } & 6 \text { months } & 6 / 21 / 50 \\ 9 / 2 / 50 & \text { Hab. Drunk. } & 3 \text { months } & 9 / 25 / 50 \\ 11 / 10 / 50 & \text { Vagrancy } & 3 \text { months } & 1 / 26 / 51 \\ 1 / 31 / 51 & \text {. Vagrancy } & 3 \text { months } & 4 / 18 / 51 \\ 5 / 24 / 51 & \text { Vagrancy } & 3 \text { months } & 8 / 10 / 51 \\ 8 / 12 / 51 & \text { Vagrancy } & 3 \text { months } & . .\end{array}$

\section{Policy Objectives of Vagrancy Law Enforcement}

Philadelphia magistrates observed during this study frequently expressed the policies which guided their administration of vagrancytype law. They viewed their function as a deterrent one to banish "bums" from Philadelphia and keep them out ("After this you stay where you belong"), or as a form of civic sanitation ("I'll clean up this district if I have to stay here until 5 o'clock every afternoon"), or as control of suspicious persons ("There have been a lot of robberies around here. I'm going to have you investigated-three months"), or as humanitarian ("I'm saving his life by sending him where he can't booze").

The wide scope of these policy objectives illustrates the important place of vagrancy-type law in our criminal administration. The acts which are made punishable are petty in terms of social dangerousness, but the chief significance of this branch of the criminal law lies in its quantitative impact and administrative usefulness. More persons are arrested for vagrancy proper than for any of the more serious offenses except possibly larceny and assault, ${ }^{20}$ and it is quite likely that more persons are convicted for this offense than for any other. ${ }^{21}$ Add the

20. Arrests for vagrancy between 1940 and 1946 ranged between $5.7 \%$ and $8.8 \%$ of all arrests tabulated in the Uniform Crime Reports. Major categories in 1945 were: drunkenness $(22.9 \%)$, larceny $(9.2 \%)$, assault $(7.9 \%)$, disorderly conduct $(7.0 \%)$ and vagrancy $(6.2 \%)$. Of all arrests in that year, $6.6 \%$ were for "suspicion," and no other charge was ever made. UNIFORM CRIME REPORTS (U.S. Dep't of Justice) for the years indicated: 1951 at $105 ; 1950$ at $107 ; 1949$ at $112 ; 1948$ at $114 ; 1947$ at $115 ; 1946$ at $116 ; 1945$ at $113 ; 1944$ at $91 ; 1943$ at $87 ; 1942$ at $86 ; 1941$ at $203 ; 1940$ at 204.

21. This may result because (1) the overwhelming number of those arrested for drunkenness are probably merely discharged, and (2) many persons arrested for vagrancy, including many in Philadelphia, were not tabulated in these reports because they were not fingerprinted. 
related offenses of drunkenness and disorderly conduct, and vagrancytype crime accounts for more than one third of all arrests tabulated in the Uniform Crime Reports. ${ }^{22}$ Then there are the countless additional arrests made for these offenses which are never recorded with the Federal Bureau of Investigation. ${ }^{23}$

Administratively, vagrancy-type statutes are regarded as essential criminal preventives, providing a residual police power to facilitate the arrest, investigation and incarceration of suspicious persons. When the District of Columbia vagrancy law was revised ten years ago, Congress was told by police officials ". . . that one of the principal needs to assist in correcting the existing criminal situation in the District of Columbia is the strengthening of the existing vagrancy law." 24 In most jurisdictions these statutes are sufficiently indefinite to give the police wide scope. They permit arrest without warrant and summary prosecution without jury before a justice of the peace or magistrate, and often simplify the problem of proof by placing on the defendant the burden of at least going forward with evidence of innocence. To the extent that the police actually are hampered by the restrictions of the ordinary law of arrest, ${ }^{25}$. by the illegality of arrests on mere suspicion alone, ${ }^{26}$ and by the defects and loopholes of substantive criminal law, vagrancy-type statutes facilitate the apprehension, investigation or harassment of suspected criminals. When suspects can be arrested for nothing else, it is often possible to "go and vag them." ${ }^{27}$

This usefulness as a criminal catch-all is not confined to its effectiveness against criminal suspects. Perhaps its principal employment is as a clean-up measure in dealing with the problems of congested urban "skid row" districts. Unwanted drunkards, panhandlers, gamblers, peddlers or paupers are committed or banished, a procedure that is alleged to deter other like persons from entering or remaining in a given locality. Miscellaneous problems in practice are embraced within its broad scope; during the period of this study in Philadelphia, vagrancy

22. The combined arrests for vagrancy, disorderly conduct, drunkenness and suspicion constituted the following proportion of all arrests for the years indicated: 1951, $39.4 \% ; 1950,40.2 \% ; 1949,41.8 \% ; 1948,42.8 \% ; 1947,43.1 \% ; 1946,42.6 \% ; 1945$, $42.7 \%$; 1944, 42.6\%; 1943, 45.3\%. UNIFORM CRIME REPORTS, op. cit. supra note 20.

23. Statistics in the Uniform Crime Reports are based on fingerprints registered with the F.B.I., and in respect to offenses such as vagrancy and drunkenness, they are incomplete to a degree which cannot be ascertained. In Philadelphia, when this field study was made, such persons were not fingerprinted on arrest, and only a few of those convicted were fingerprinted at the House of Correction; thus the great majority were not included in the F.B.I.'s statistics.

24. H.R. REP. No. 1248, 77th Cong., 1st Sess. 1 (1941).

25. See Note, Philadelphia Police Practice and the Law of Arrest, 100 U. PA. L. REv. 1182 (1952).

26. Stoutenburgh v. Frazier, 16 App. D.C. 229, 48 L.R.A. 220 (1900).

27. People v. Craig, 152 Cal. 42, 47, 91 Pac. 997, 1000 (1907). 
convictions were used at least twice to imprison unsuccessful would-be suicides and repeatedly as a means of commitment of mentally ill persons.

It is somewhat incongruous that these modern and peculiarly urban problems are dealt with by statutes created centuries ago to meet the utterly dissimilar problems of a rural England faced with the break-up of feudalism and its resulting economic dislocation. The basic elements of the Pennsylvania vagrancy statute merely repeat legislation enacted 400 years ago in the immediate aftermath of the Black Death. Despite the drastic change in social and economic conditions that has intervened, there is striking similarity between the policy objectives of modern vagrancy law administration and of the pre-Elizabethan Parliaments.

\section{Banishment of Unwanted Persons}

\section{Feudal Background}

The anti-migratory policy behind vagrancy legislation began as an essential complement of the wage stabilization legislation which accompanied the break-up of feudalism and the depopulation caused by the Black Death. By the Statutes of Laborers in 1349-51, every ablebodied person without other means of support was required to work for wages fixed at the level preceding the Black Death; it was unlawful to accept more, or to refuse an offer of work, or to flee from one county to another to avoid offers of work or seek higher wages, ${ }^{28}$ or to give alms to able-bodied beggars who refused to work. ${ }^{29}$ By a later act, the penalties of branding, slavery and death were to be inflicted even upon those unable to get work for wages who ". . . do not offer themself to work for meate and drynk." 30 The Act of 1414, noting that laborers were continuing to flee from county to county ". . . to the great damage of gentlemen and others to whom they should serve . . ." sought to tighten up enforcement by giving justices of the peace the summary power to punish vagrants which they have exercised ever since. ${ }^{31}$

This attempt to make the vagrancy statutes a substitute for serfdom by tying workers to their jobs was an economic failure. Lack of work or wretched working conditions continually forced laborers onto the road, and until

28. 25 Edw. 3, c. 7 (1350-51). For a summary of these statutes, see 3 STEPHEN, History of the Criminal Law of England 203-06 (1883). For a compilation, see DEPARTMENTAL COMMITTEE ON VAGRANCY, REPORT app. 1 (London 1906).

29. 23 Edw. 3, c. 7 (1349).

30. 1 Edw. 6 , c. 3 (1547).

31. 2 Hen. 5 , c. 4 (1414). 
". . . the middle of the 17th Century, and indeed, although in diminishing degree right down to the reform of the poor law in the first half of the 19th century, the roads of England were crowded with masterless men and their families, who had lost their former employment through a variety of causes, had no means of livelihood, and had taken to a vagrant life." 32

These conditions changed the emphasis of the anti-migratory policy from required work at a fixed abode to protection of the countryside against the financial burden, nuisance and potential criminality of the vagrant class. The ban upon migration became a preventive to keep a parish, which had the responsibility of providing relief for local needy residents, from being burdened with the annoyance and economic liability of foreign paupers and idlers. The laws were accordingly drawn to confine those unable to work to their own parish; if they wandered, they were liable to punishment and compulsory removal to the parish which was legally bound to support them. Those who refused to work although able to do so were viewed with hostile eyes, not only because of the suspicion they aroused but as a potential relief burden.

This policy was carried over to this country, some vagrancy statutes dating from colonial times. "Paupers" and "vagabonds" were excepted from the privileges and immunities clause of the Articles of Confederation and from its guarantee of ". . . free ingress and egress to and from any other state." 33 In City of New York v. Miln, ${ }^{34}$ the Supreme Court noted that it is ". . . as competent and as necessary for a state to provide precautionary measures against the moral pestilence of paupers, vagabonds, and possibly convicts, as it is to guard against the physical pestilence. . . ." During the depression some states established "border patrols" to keep out unwanted migrants, ${ }^{3 \bar{J}}$ and statutes for this purpose were adopted in twenty-seven states prior to $1940,{ }^{36}$ when they were declared unconstitutional. ${ }^{\mathbf{3 7}}$

32. Scott, L.J., in Ledwith v. Roberts, [1936] 3 All E.R. 570, 585, 594 (C.A.). "The main causes were the gradual decline of the feudal system under which the labouring classes had been anchored to the soil, the economic slackening of the legal compulsion to work for fixed wages, the breakup of the monasteries in the reign of Henry VII, and the consequent disappearance of the religious orders which had previously administered a kind of public assistance in the form of lodging, food and alms; and lastly the economic changes brought about by the Enclosure Acts." Ibid.

33. "The free inhabitants of each of these States, paupers, vagabonds, and fugitives from justice excepted, shall be entitled to all the privileges and immunities of free citizens in the several States, and the people of each State shall have free ingress and egress to and from any other State." Article IV (Emphasis added). AMrerICAN's GuIDE AND Constirumions 554 (1855). See Note, Depression Migrants and the States, 53 HARV. L. REV. 1031, 1036 n.34 (1940).

34. 36 U.S. (11 Pet.) 102, 143 (1837) (1940)

35. See Note, Depression Migrants and the States, 53 Harv. L. Rev. 1031, 1034

36. Id. at 1033 .

37. Edwards v. California, 314 U.S. 160 (1941). See discussion in text at notes 60-64 infra. 
It is incongruous that this Elizabethan and pre-Elizabethan antimigratory policy should have been imposed in a country where mobility of population has played a role of such historic and economic importance. Vast movements of people motivated by urgent economic need settled this country from Europe, pushed settlement westward and fed growing cities from rural population reservoirs. England's Enclosure Acts, by withdrawing land from agricultural use, swelled the army of English vagrants; America invited migration with the lure of free land. The same elements of the population who on one side of the Atlantic were rogues and vagabonds, on the other were frontiersmen. Nor are such migrations ended, although there is no longer a frontier for a shock-absorber. Negroes moving out of the South and farmers driven out of the Great Plains Dust Bowl are two recent examples, and vagrancy law and its anti-migratory philosophy has exerted substantial if inconclusive deterrent weight against both.

The most important factor which contributes to migration of persons in the lower economic brackets today is the need for transient labor resulting from the mechanization of agriculture. Between 1931 and 1949 , the proportion of farm workers who were needed twelve months a year declined from 46 per cent to 19 per cent, and the proportion of workers needed two months or less rose from 11 per cent to 27 per cent. $^{38}$ In 1950, agricultural employment ranged from a December low of 6.7 million persons to a September high of 13.7 million. ${ }^{39} \mathrm{Mi}$ gratory workers are essential to meet these fluctuating demands, and this labor supply is drawn of necessity from the lowest economic strata of society. These facts dramatize the absurdity of applying preElizabethan anti-migratory policy to the America of the nineteenfifties.

\section{Philadelphia's Banishment Policy}

This fifteenth century policy objective of erecting barriers against the wanderings of the poor and of banishment of those who were found where they were not supposed to be retains surprising vitality in present day Philadelphia vagrancy administration. Any migrant, whether a transient en route between jobs, or stopping over to spend the proceeds of one job before moving on to the next, or arriving in a city destitute and planning to stay there while seeking employment, is bait for a vagrancy arrest. ${ }^{40} \mathrm{He}$ tends to gravitate to the skid row in any

38. PRESIDENT'S CoMMission on Migratory Labor, REPORT 12 (1950).

39. Hearings Before Senate Committee on Agriculture and Forestry on S. 949, 82d Cong., 1st Sess. 11 (1951). See Tyson, Migratory Labor-Sone Legal, Social and Economic Aspects, 3 MERCER L. REv. 278 (1952).

40. See Bower v. State, 135 N.J.L. 564, 53 A.2d 357 (Sup. Ct. 1947) : "It is not an offense to have a dirty face, or to wear blue overalls or to travel by gratuitous 
city through which he passes, if only because that is where $50 \%$ beds can be obtained, and he can patronize the bars, walk the streets, or sit on a park bench on a warm summer night. Some, but by no means exclusively the drinkers, ${ }^{41}$ get scooped up in the nightly rounds of clean-up arrests. They constituted a small but significant minority of the drunkenness and vagrancy prosecutions observed in this study. In the magistrates' courts their defense of recent employment or search for employment was viewed with such extreme suspicion that it was very difficult to establish.

Some examples will illustrate the operation of the anti-migratory policy in Philadelphia. On a July morning after one of the hottest nights of the summer, a group of defendants were brought before a Philadelphia magistrate. A police officer checked the record of arrests and said: "These men were arrested sleeping in Reyburn Plaza at 2:20 a.m." The arresting officers were not present, and there were no other witnesses.

The magistrate took them one by one, first asking each one, "Where are you from?" If the answer was Philadelphia, the defendant was discharged with a warning not to sleep outdoors in a park again.

In each case where the defendant's answer revealed an out-of-city residence, even when the defendant tried to say more, the magistrate immediately concluded the hearing with, "You can't sleep in the parks. Three months in the House of Correction." The commitment sheets showed that these men were convicted of vagrancy.

A number of American jurisdictions have emulated the British statute which prohibits what has been called the "scandal" 42 of "sleeping in . . . the open air" by persons "who can give no good account of themselves." 43 Pennsylvania does not have this statutory provision. Thus, its enforcement can only be described as punishment by

rides from Bangor, Maine, to Florida, or to sleep in a truck, or to pick potatoes in one part of the country or, with $\$ 14$ in pocket, to be temporarily out of employment on the way from completion of one job to the search for another." The conviction of this defendant, arrested under the circumstances described, was reversed; but in vagrancy such a rare appeal may very well indicate arrest practices which continue despite a decision. "Typically, the policemen are given little information about the laws they are required to enforce, and they are usually unaware of appellate decisions that affect the meaning of those laws whose texts they may have read." Note, 59 Y ALE L.J. 1351, 1357 (1950).

41. In the 6 th police district in June, 1951,18 of 46 vagrancy arrests were listed as "sober" and 28 "drunk" on arrest.

42. Departmental Commithee on Vagrancy, Report 326 (London 1906).

43. E.g., Conn. GEN. STAT. $\$ 8644$ (1949) ;DeL. CodE ANn. tif. 11, §881 (1953); D.C. Code ANn. $\$ 22-3302(6)$ (Supp. 1949); Mass. AnN. Laws c. 272, §66 (1933); N.J. Stat. ANn. \& 2 A :170-4 (1952) ; N.Y. PEN. CODE $\$ 887(6)$. 
analogy, and in any case, the "good account" proviso is essential unless the offense is to include boy scouts, naturalists or persons taking a nap under a tree on a hot day. ${ }^{44}$

The convicted defendants were subsequently interviewed in the House of Correction. $A$ and $B$ stated that they were staying in skid row hotels while visiting Philadelphia, and it was so hot that they went out to sit in the park and fell asleep. $A$ declared, "The next thing I knew they were kicking me in the shins and told me to get into the wagon."

A middle aged man, $C$, reported that he worked nine months a year in a cotton seed oil processing plant in Virginia, where he had a wife and three children, and that during the seasonal shut-down of the plant he worked as an agricultural migrant. He alleged that he had worked on a New Jersey farm on the day of his arrest, came in to visit Philadelphia in the evening on the labor contractor's truck, had some drinks and missed the truck back. He said he went to the bus station to wait for the first early morning bus, but it was so hot there that he retreated to the park and was arrested.

$D$ and $E$ were Negro youths of about 20. $D$ said he was en route from New York, where he had been working, to his home in Mississippi; he arrived in Philadelphia by bus in the evening and wanted to stay over to look around and see a friend. They lounged in the bus station for a while, walked up Market Street, decided against taking in an all night movie, and ended up on the park bench. $D$ had $\$ 25$ on his person at the time of his arrest to finance his trip to Mississippi. ${ }^{45}$ All of these defendants were listed as "sober" when arrested, and none of them fitted the stereotype of "bum."

Transient types observed during the study included: (1) agricultural migrants, like $C$ in the above example; (2) men who alleged they had just come to Philadelphia hoping to stay and find employment, like the Virginian noted above; (3) men who alleged that they had stopped in Philadelphia to visit friends or "to see the sights" (To one of the latter a magistrate said: "I'll show you some sights-three months in the House of Correction") ; and (4) one non-resident seaman. This man was interviewed at the House of Correction. He said he had come off a ship with $\$ 175$, which he proceeded to spend in a

44. But see CoNN. GEN. STAT. $\$ 8644$ (1949) (vagrants include "all persons camping on the public highway without the consent of the selectmen of the town or on private property without the consent of the owner. . . ."); see also WIs. STAT. \$ 348.351 (1953), as amended, WIs. IAws 1951, c. 332 (no "good account" exception).

45. At the House of Correction it was later confirmed that $C$ had a Virginia residence, wife and children, and that $D$ was from Mississippi. Police records confirmed $D$ 's claim to have had $\$ 25$ on him at the time of his arrest. 
week-long binge. About the third time he appeared before a magistrate, he was committed.

When the transient defendant is allowed to have his say before the magistrate, the defenses he advances are often difficult to substantiate. One who alleges that he has been working in New York and is en route to Baltimore to get a job has no practical way of proving either statement. Nor is it reasonable to expect a defendant who claims that he is seeking work in Philadelphia to produce as witnesses the men who have turned him down for a job. Under the pressure of time and mass production in the magistrates' courts, questions of proof are greatly simplified. One defendant stated that he was from Trenton, New Jersey, and that he was in Philadelphia looking for work. "Why didn't you get work in Trenton?" "I tried. I was registered with the Employment Service there, but I didn't get anything so I came down here." He was then committed. When interviewed later, he said that he had intended to register with the U.S. Employment Service in Philadelphia, but had not had a chance, because he had been arrested within a few hours after his arrival.

One morning two men who had been arrested as intoxicated but whom the magistrate was apparently trying as transients, and therefore for vagrancy, told similar stories. The first claimed that he had come from Richmond en route to New York and had stopped to see a girl friend. The second alleged that he had come from Baltimore to pick up some laundry which he had forgotten to take with him after a previous visit here. There was no prosecution evidence in either case except the fact of arrest. The first man was committed for three months as a vagrant; the second, the magistrate discharged with these words: "You get your laundry and be on your way to Baltimore by two o'clock this afternoon. If you're picked up here again you'll go to Correction."

After the hearing the magistrate distinguished the cases, explaining that after years of experience on the bench one becomes a pretty good judge of men. "Some people, you look at them, you know they're lying." But this simple and time-saving substitute for direct examination, cross-examination and impeachment occasionally backfired. One such case was that of a young man who claimed he both lived and worked in Philadelphia but was without identification. The magistrate gave him a half minute of quizzical study and sentenced him to six months. Half an hour later, as the prisoners were being loaded into the van and the magistrate was picking up his papers, a man who turned out to be the defendant's employer came in and substantiated the defendant's story. The defendant was brought back from the van, the 
magistrate tore up the commitment sheet he had signed and gave a discharge. ${ }^{46}$

A defendant whose employer did not thus seek him out was not so fortunate. He was a 21-year old Indian arrested intoxicated late at night by railroad police in Broad Street Station, and he was found to have a knife concealed on his person. ${ }^{47}$ This trial was not observed, but when interviewed the defendant stated that the following proceedings took place: the magistrate asked him where he was from, and he replied with his Philadelphia addres's. "I mean, where are you from originally." "Oklahoma." "You're a vagrant. One year in the House of Correction." This defendant claimed that he was not allowed to telephone anyone before the hearing commenced, that when he tried to say something more at the hearing he was grabbed by two officers and dragged back to his cell, and that not until he had been at the House of Correction for several days was he allowed to contact anyone. $\mathrm{He}$ stated that he had come to Philadelphia a month before, that he was employed in a photographic supply store on Market Street, and that the reason he had a knife (which he said was "nothing but a small penknife") was because he used it in his work. The employer confirmed this man's story, stated that he was a good worker and that when he had learned what had happened, he had gone to see the magistrate who refused to do anything.

The exclusionary policy was often applied in cases of acquittal, with defendants being discharged on the sole condition that they get out of Philadelphia. To one who said he had come to Philadelphia for a week's visit, the magistrate said, "You cut your week short and get out today." A defendant, who said he was from Trenton, declared that he had come to Philadelphia to see a friend. "You were panhandling, too, weren't you ?" "Oh no, judge." "Well, let me warn you. Don't come back here again, or you go up to Correction. No more panhandling. Discharged." As the defendant left, the police officer who served as the magistrate's "clerk" called after him: "You go back up to Trenton. You do your panhandling up there, see?"

Some of the cases which have been discussed indicate that magisterial anti-migratory policy was not confined to transients but was used

46. "It shall be unlawful for any magistrate to (a) Review, alter, modify or remit any sentence of fine or imprisonment imposed by him. . ." PA. STAT. ANN. tit. 42, $\S 1144$ (Purdon Supp. 1953).

47. Id. tit. 18, §4416 (Purdon 1945) provides that "Whoever carries any . . . deadly weapon, concealed upon his person, with the intent therewith unlawefully and maliciously to do injury to any other person, is guilty of a misdemeanor. ..." (Emphasis added.) This defendant, however, was not charged with this offense and in view of his explanation for carrying the knife (supra), it is probable that he could not have been convicted under it. 
to deter intra-city travel. A very small minority of Philadelphians arrested in the skid row district but resident in another part of the city were convicted, the magistrate remarking, "He should stay where he belongs." More often there were discharges with a warning to "keep away from this district."

Even the statutory and administrative release procedures were geared to this policy of banishment. A statute (which was apparently in disuse) provides that upon release of a vagrant, he shall be given a certificate of discharge ". . . which shall exempt him from any further arrest for vagrancy for a period of five days upon condition that he shall forthwith leave the county wherein confined. . . " 48 Banishment was also enforced as a condition of an informal "parole" given some vagrancy inmates at the House of Correction in 1951. At that time some of the transients who were committed as vagrants were visited by a probation officer of the Municipal Court. If their residence claims in other states were confirmed and they either had or could obtain funds to finance a bus ticket home, they were taken before a $\mathrm{Mu}$ nicipal Court judge and given parole on condition that they go straight home. ${ }^{49}$ The probation officer accompanied them to the bus terminal to make sure that they really left.

One possibly important aspect of anti-migratory policy cannot be evaluated on the information available in this study. It was reported that some vagrant-type defendants were threatened with arrest for vagrancy, but were let off by the police officer with a warning to get out of town. This practice has been recommended as a means whereby vagrancy law could be enforced "at the least possible expense to the taxpayer," ${ }^{50}$ but there is no way of testing the frequency with which it occurs.

\section{Validity of Banishment Sanction}

In one of the earliest criminal prosecutions on American soil, the penalty inflicted upon Ann Hutchinson in 1637 was to be ". . . banished from out of our jurisdiction as being a woman not fit for our society . . . ," ${ }^{51}$ and in 1800, a legislative imposition of banishment was upheld. ${ }^{52}$ Whether or not a legislature today has the constitu-

48. PA. Stat. ANN. tit. 18, $\$ 2042$ (Purdon 1945).

49. This type of parole appears to have no statutory authority, and the procedures followed have since been changed.

50. Commonwealth v. Dean, 19 Pa. Dist. 534 (Bradford County C.P. 1909). "In most cases those who are in fact vagrants if notified by officers to leave the vicinity or suffer arrest would immediately take their departure." Id. at 537.

51. Quoted in Douglas, An Almanac of Liberty 135 (1954).

52. Cooper v. Telfair, 4 U.S. (4 Dall.) 14 (1800) upheld a Georgia statute banishing from the state named persons who had sided with England during the Revo- 
tional power to impose such a punishment may be open to question, ${ }^{53}$ but it is agreed that in the absence of express legislative authority, a sentence which includes banishment is void. ${ }^{54}$. No Pennsylvania statute authorizes banishment as a punishment for crime. Technically the orders by which magistrates banish defendants in Philadelphia are not sentences, for a discharge is given upon condition that the defendant leave the city or a particular district within the city. The result is the same, however, as the "floating sentence" outlawed in a California case in which a two year sentence was suspended on condition that the defendant leave the county and stay away for two years, ${ }^{55}$ and in the New York case where execution of sentence was stayed for 24 hours ". . . to give the defendant a chance to leave Town and not come back." " been stressed by the courts apply in full force to Philadelphia practices. It is no solution to the problem posed by the urban derelict to pass him back and forth from one jurisdiction to another, ${ }^{57}$ and if, as seems highly likely, other jurisdictions are doing the same thing, such a policy is ultimately self-defeating. ${ }^{.8}$

A more basic concern is the fact that the anti-migratory policy of vagrancy administration squarely contravenes the right of persons to travel freely from state to state. While the Supreme Court once said in City of New York v. Miln that it is ". . . as competent and as necessary for a State to provide precautionary measures against the moral pestilence of paupers, vagabonds, and possibly convicts, as it is to guard against physical pestilence . . . , "ִ9 that 1837 decision

lution. Justice Cushing said: "The right to confiscate and banish, in the case of an offending citizen, must belong to every government. It is not within the judicial power, as created and regulated by the Constitution of Georgia; and it, naturally, as well as tacitly, belongs to the Legislature." Id. at 19.

53. It has been suggested that today such legislative action might be banned as cruel and unusual punishment. People v. Wallace, 124 N.Y.S.2d 201, 204 (Suffclk County Ct. 1953).

54. In re Scarborough, 76 Cal. App. 2d 648, 173 P.2d 825 (1946); Ex parte Baum, 251 Mich. 187, 231 N.W. 95 (1930); State v. Doughtie, 237 N.C. 368,74 S.E.2d 922 (1953); People v. Wallace, sutpra note 53; State v. Baker, 58 S.C. 111, 36 S.E. 501 (1900). See Cooper v. Telfair, 4 U.S. (4 Dall.) 14, 19 (1800) (dictum) ; United States v. Ju Toy, 198 U.S. 253, 269 (1905) (dissenting opinion). However, it has been held that a pardon conditioned on banishment is valid. Kavalin v. White, 44 F.2d 49 (10th Cir. 1930); see Comment, 31 Mrnn. L. Rev. 742, 743 (1947).

55. In re Scarborough, 76 Cal. App. 2d 648, 173 P.2d 825 (1946).

56. People v. Wallace, 124 N.Y.S.2d 201, 203 (Suffolk County Ct. 1953).

57. In State v. Doughtie, 237 N.C. 368, 371, 74 S.E.2d 922, 924 (1953), the court noted that "It is not favorable to him to force him to go for two years into another state, where the state of North Carolina can exercise no restraining influence upon him for purposes of reformation."

58. Compare the prediction of the Michigan Supreme Court that banishment of criminals "would tend to ... provoke retaliation." Ex parte Baum, 251 Mich. 187, 231 N.W. 95 (1930).

59. 36 U.S. (11 Pet.) 102, 142 (1837). 
has little validity in view of Edwards $v$. California. ${ }^{60}$ There the Supreme Court held unconstitutional a statute which banned importing indigent persons into a state. The majority rested their decision on the statute's repugnance to the commerce power; three Justices applied the privileges and immunities clause; and one Justice thought the statute void under both clauses." The majority pointed out that ". . . the theory of the Elizabethan poor laws no longer fits the facts" and specifically repudiated Miln: "Whatever may have been the notion then prevailing, we do not think that it will be seriously contended that because a person is without employment and without funds he constitutes a 'moral pestilence.' ", 62

Yet a major part of Philadelphia's vagrancy administration rests on just such a contention. Cases were repeatedly observed in which "because a person is without employment and without funds," conviction resulted. However the Edwards case is viewed, it clearly bans restrictions against persons whose interstate travel is for any lawful purpose. The inevitable effect of vagrancy statutes is to impede such travel, and Philadelphia practice accentuates this by its conscious effort to deport persons who are chiefly undesirable because of their poverty, and to deter such persons from coming to the city. The Pennsylvania statute is particularly vulnerable under the Edwards case because it singles out interstate migrants and limits vagrants to those who have come from without the state. ${ }^{63}$ But the Philadelphia practice and the statutes of other jurisdictions which also embrace intrastate migration within vagrancy would also seem to be invalid under the Edwards policy. A state cannot allow a migrant to enter but then restrict his freedom of movement; the freedom to enter the state of one's choice is more than the freedom to be sent to a restricted ghetto. ${ }^{64}$

60. 314 U.S. 160 (1941).

61. Despite the failure of the majority to expressly rule on the privileges and immunities point in Edwards $v$. California, it seems to be well established that the right to enter and reside in any state of one's choice is a right arising "out of the nature and essential character of the national government." Twining v. New Jersey, 211 U.S. 78, 97 (1908). Before the fourteenth amendment was adopted, the Court invalidated a Nevada tax on persons leaving that state as inconsistent with the right incident to national citizenship to travel across the country without restriction. Crandall v. Nevada, 73 U.S. ( 6 Wall.) 35 (1867). The Third Circuit sustained an injunction to restrain the police from exporting C.I.O. organizers from Jersey City on the grounds that freedom of movement between states is protected by the privileges and immunities clause. Hague v. CIO, 101 F.2d 774 (3d Cir. 1939); see also Allgeyer v. Louisiana, 165 U.S. 578,589 (1897) (fourteenth amendment includes right "to live and work where he will"). "If national citizenship means less than this, it means nothing." Edwards v. California, 314 U.S. 160, 183 (1941) (concurring opinion of Justice Jackson).

62. 314 U.S. at $174,177$.

63. See note 8 supra.

64. "Individuals coming into or going about a city upon their lawful concerns must be allowed free locomotion upon the streets and public places." Hague v. CIO, 101 F.2d 774, 780 (3d Cir. 1939). 


\section{Suspicion}

We have seen that in Philadelphia many vagrant-type defendants are banished merely because their poverty-often but not always combined with alcoholism-makes them aesthetically undesirable on the city's streets and parks, a practice which carries out the Poor Law policy that pauperism alone is sufficient reason to compel people to "stay where they belong." There is, however, a second important factor involved in the policy of exclusion, banishment and control of vagrant-type defendants. It has been thought that the circumstances under which vagrant-type defendants are frequently apprehended are sufficiently suspicious to raise a reasonable inference that criminal conduct other than vagrancy or drunkenness is involved. It is important to note that two quite different kinds of suspicion are involved. The alleged vagrant may be suspected of past criminality, the arrest for vagrancy offering the opportunity to investigate whether the suspect is wanted in another jurisdiction or has committed other crimes. ${ }^{65}$ On the other hand, the suspicion may be of future criminality, the inference being that purposeful poverty is likely to lead to other crimes unless the state steps in.

The commonest judicial explanation of vagrancy's place in a penal code is based on the second of these assumptions. The traditional view expressed in cases and texts is that the vagrant mode of life denounced by the statutes is of itself a crime breeder and the vagrant "the chrysalis of every species of criminal." 68 This view appears very early in vagrancy's legislative history ${ }^{67}$ and courts have continued to echo the preamble of a pre-Elizabethan statute that ". . . idleness and vagabondry is the mother and root of all thefts, robberies, and all evil acts, and other mischiefs . . . ." 88 Vagrancy statutes are viewed as "police regulations to prevent crime," ${ }^{69}$ to check the spread of "a parasitic disease" 70 which is not only evil in itself but

65. For a recent example of this see, the following news item: "Tony Labandeira, 35, was released from the Dawes County jail Monday morning after serving a 10-day sentence for vagrancy during which he was questioned about the rape-slaying of Donna Sue Davis in Sioux City, Ia." Lincoln (Nebr.) Star, July 2, 1955, p. 16, col. 1.

66. Tieneman, Limitations of Police Power 117 (1886).

67. The earliest reference was to vagabonds as "idle, and suspected persons." 11 Hen. 7 , c. 2 (1494).

68. 1 Edw. 6, c. 3 (1547).

69. In the Matter of Forbes, 11 Abb. Pr. 52, 55 (N.Y. Sup. Ct. 1860) ; see Commonwealth v. Roth, $136 \mathrm{~Pa}$. Super. 301, 304, 7 A.2d 145, 146 (1939). "The . . . idea that "where there is smoke there must be fire' is the reason why vagrancy has been a crime for centuries." Note, 80 U. PA. L. REv. 565, 568 (1932).

70. State v. Harlow, 174 Wash. 227, 233, 24 P.2d 601, 603 (1933). 
"productive of innumerable vices and crimes of great magnitude." 71 Thus, the arrests are supposed to "check evil in its beginning" 72 and "prevent crime by disrupting and scattering the breeding spot." 73

This theory that purposeful poverty will lead to other criminality has a certain basis in common sense, for if a man is idle with no means of support, "there is a great temptation to steal in order to relieve his hunger." 74 But that statement suggests the rationale's limitations, for if the necessity of self-support is what turns the vagrant to crime, that criminality may be of a very petty nature. ${ }^{75}$ The most common example is undoubtedly begging which, although usually proscribed by statute or ordinance, ${ }^{76}$ still retains strong public tolerance carried over from religious teaching on giving and the tradition of holy men living upon alms. ${ }^{77}$ The sanction against begging has not repressed the practice ${ }^{78}$ and is not vigorously enforced, with the result that there are sufficient funds to be coaxed out of the public to meet the demands of those who seek merely a meal, a bed or another drink. A man with such limited objectives is not forced into very serious criminality to obtain gratification.

Nor does it necessarily follow that one who is idle and apparently without means of support will turn to criminality. When completely down and out, he may be able to go on relief or to obtain help from friends or relatives. Many casual workers obtain jobs between periods of unemployment-which last as long as any funds remain-after which they may ship out to sea, go back to migratory agricultural labor or seasonal industrial work or even get a job right in the skid

71. County of Northampton v. West, $28 \mathrm{~Pa} .173,175$ (1857). 1933).

72. Levine v. State, 110 N.J.L. 467, 470, 166 At1. 300, 302 (Hudson County C.P.

73. People v. Pieri, 269 N.Y. 315, 323, 199 N.E. 495, 498 (1936).

74. Daniel v. State, 110 Ga. 915, 916, 36 S.E. 293 (1900).

75. See notes 80-83 infra.

76. E.g., Colo. Stat. Ans. c. 48, $\$ 281$ (1935) ; Vr. Rev. Star. $\$ 8444$ (1947). In Philadelphia several magistrates informed me that begging is punished as straight vagrancy, although no such cases were observed. Compare the tramp statute, PA. STAT. ANN. tit. 18, $\S 4617$ (Purdon 1945), which covers begging but which is a misdemeanor.

77. "... [T] [There grew up in the course of time the theory of the religious merit of almsgiving. Charity became a means of securing forgiveness of sin to the giver, a means of grace. Almsgiving, no longer the means primarily of helping a fellow-man in need, became fundamentally a method of washing away one's sins.

"With the rise of monasticism in Christendom the religious basis of begging in the cleansing grace of charity was completed in the theory that those were of superior sanctity who forsook all their worldly possessions and depended entirely upon the charity of God's people. Thus, the religious basis of beggary had its roots deep in man's desire to free himself from sin by giving to a beggar, and on the other hand got its justification from the desire to attain salvation by becoming a beggar. From both points of view religion sanctified begging." Gillin, Vagrancy and Begging, 35 As. J. Soc. 425,426 (1929).

78. "Excepting prohibition, there is probably no problem in which attempts at control appear to have been a more blatant and universal failure than they have in the case of begging." GILMORE, The BeGGAR 213 (1940). 
row. A man willing to undergo the very low standard of living of the stereotype vagrant may, like Thoreau in Walden, work at odd jobs only to the extent necessary to provide for his limited needs. Men whose stories would place them in each of these categories were interviewed at the House of Correction, and they find occasional recognition in the reported cases. ${ }^{\text {79 }}$

No adequate studies have been found to correlate the incidence of other criminality among vagrants and thus test the validity of this breeding-ground theory. Probably no such study could be made, for police practices have little relationship to this judicially-created rationale. Even if it could be determined that persons arrested for vagrancy also had a high-incidence of other criminality, little light would be thrown on the breeding ground theory, for the police make many arrests for vagrancy without regard to whether or not the arrested person falls into the status of a vagrant.

Such material as is available, however, lends weight to the belief that there is little correlation between pauperism and serious criminality. A study of the prior convictions of a sample of inmates admitted to the Philadelphia House of Correction reveals fairly high recidivism confined to other vagrancy and habitual drunkenness convictions but a low-rate of recidivism for other more serious crimes. ${ }^{80}$ Even writers who support the "breeding ground" rationale also state that it does not breed dangerous criminality. ${ }^{81}$ The British Vagrancy Committee's exhaustive study in 1906 reported that "the witnesses who have given evidence before us agree that the vagrant class as a whole is not much addicted to the worse forms of crime, but minor offenses are very common," citing petty larcenies from the back doors of houses

79. Leonard v. State, 5 Ga. App. 494, 63 S.E. 530 (1909) (defendant who usually loafed not a vagrant when earning enough to live in meager style); Lewis v. State, 3 Ga. App. 322, 59 S.E. 933 (1907); Senegal v. State, 112 Tex. Crim. 408, 16 S.W.2d 1070 (1929) (idling around pool halls by longshoremen with only occasional employment held not vagrancy).

80. See Hiller \& Rector, Intake and Release Procedures in tue House of Correction, PhILAdelpHIA, PA. (Nat'l Probation \& Parole Ass'n 1953) (mimeo). For the recidivism of all 164 inmates studied, see $i d$. table I at 94 ; of 134 males, see id. table $\mathrm{K}$ at $96-97$. Of the cases studied, 61 were defendants serving vagrancy or habitual drunkenness sentences, of whom 24 appeared to be first commitments, 29 had prior commitments for vagrancy or habitual drunkenness, and only 8 had other criminal records, of which several appeared to be for minor criminality only.

81. For an example of this confusion compare the following excerpts from DAwSon, The Vagrancy Problem (1910):

"Dislike of regular labor makes them tramps, tramping makes them criminalsthe two conditions are inseparably connected as cause and effect, for their kinship lies in the very constitution and instincts of human nature. . . ." Id. at 37.

"It is not-in the main, at any rate-a dangerous criminal class with which we have to do, but for the most part the weak and aimless characters whose great need is the moral tonic of discipline and compulsion." Id. at 72 . 
as an example. ${ }^{82} \stackrel{a}{\mathrm{~K}}$ inberg's study of vagrants in Sweden found a large group of tramps, hobos, vagabonds and intermittent vagrants characterized by an absence of criminality in the usual sense, and he cites other European studies showing many subjects punished innumerable times for vagrancy but with no manifestations of other forms of criminality. ${ }^{83}$ This Philadelphia study appears to support these conclusions, for there was no indication by police and magistrates that they regarded the vagrants as dangerous potential criminals. Many, indeed, when in the grip of acute alcoholism, were more an object of pathos than anything else.

In any event this analysis is rendered somewhat academic because the police take a much more pragmatic view of suspicion as a policy behind vagrancy law. The arrests, both in Philadelphia and in other jurisdictions as revealed in reported cases, give little indication that the police are consciously suppressing a mode of life because it may lead to future criminality. Where suspicion of any sort is involved, it is suspicion of past criminality. In Philadelphia, magistrates would sometimes commit with some such explanation as "I'm going to have you investigated; there have been a lot of robberies around here." On a number of occasions one magistrate delivered a "You people may think I'm cruel" speech to the spectators at his hearings, one version of which would continue: "It may seem cruel to send all these people up like this, but you'd be surprised how many are wanted in other jurisdictions. Last month alone 50 of these men were wanted." (The month referred to was June, 1951; according to information supplied the writer at the House of Correction, only one of the commitments for that month was wanted in another jurisdiction.) This is a crude, freeswinging method of trying to solve past crimes, not an attack on a breeding place of potential criminals.

Cases in other jurisdictions indicate that, where suspicious circumstances cause an arrest for vagrancy, something more specific than status is involved. ${ }^{84}$ The charge may be a mere cloak for an arrest that officers have been ordered to make, ${ }^{85}$ an arrest for some other offense, as a means of validating what would otherwise be an illegal

82. Departmental Commitree on Vagrancy, Report 25 (London 1906). For an optimistic recent British report on the rehabilitative possibilities of tramps and vagrants, see editorial comment, 112 JUST. P. 727 (1948).

83. Kinberg, On So-Called Vagrancy; a Medico-Sociological Stıdy, 24 J. Crim. L., C. \& P.S. 409, 552 (1933).

84. See generally Note, Use of Vagrancy-type Laws for the Arrest and Detention of Suspicious Persons, 59 YALE L.J. 1351 (1950).

85. People v. Craig, 152 Cal. 42, 47, 91 Pac. 997, 1000 (1907). 
search. $^{86}$ The defendant may be a suspected prostitute ${ }^{87}$ or pickpocket, $^{88}$ an associate of bootleggers ${ }^{89}$ or suspected of participation in the narcotics traffic. ${ }^{90}$ He may be acting suspiciously near a saloon ${ }^{91}$ or in a $\mathrm{car}^{92}$ or by peering into store windows, ${ }^{93}$ where the facts observed do not amount to an attempt. The charge has been used to support arrests for activities which the police desire to suppress, such as "communistic agitation," ${ }^{4}$ or labor organization..$^{95}$ The San Francisco police once arrested 375 men at one time, mostly in union halls, and charged them with vagrancy. ${ }^{96}$

A traditional vagrancy statute such as Pennsylvania's is ill-adapted to such police practices. Such elements as idleness and being without visible means of support describe a status and are aimed at a mode of life, not at isolated instances of idleness. ${ }^{97}$ If the statutes were correctly construed and applied, such status elements would seriously interfere with what is now one of vagrancy's most convenient aspects from a police standpoint-the authority to arrest without a warrant on view of the offense. ${ }^{98}$ Observation of an isolated instance of idleness would not justify an arrest; an officer would have to wait until he had observed "a series of acts extending over a considerable period of time, and only constituting a criminal offense because of their continuance and repetition . . . ." 99

86. Gray v. State, 243 Wis. 57,9 N.W.2d 68 (1943).

87. Beail v. District of Columbia, 82 A.2d 765 (D.C. Munic. App. 1951), rev'd, 201 F.2d 176 (D.C. Cir. 1952).

88. Burns v. District of Columbia, 34 A.2d 714 (D.C. Munic. App. 1943).

89. Campbell v. State, 31 Okla. Crim. 39, 237 Pac. 133 (1925) ; Hutchins v. State, 172 Tenn. 108, 110 S.W.2d 319 (1937).

90. Blakeley v. State, 78 Ga. App. 516, 51 S.E.2d 598 (1949).

91. State v. Carrol, 129 N.J.L. 416, 30 A.2d 54 (Sup. Ct.), aff'd per curiam, 130 N.J.L. 559, 33 A.2d 907 (Ct. Err. \& App. 1943). 1950).

92. People v. Johnaken, 196 Misc. 1059, 94 N.Y.S.2d 102 (New Rochelle City Ct.

93. McNeilly v. State, 119 N.J.I. 237, 195 Atl. 725 (Sup. Ct. 1937).

94. In the Matter of Cutler, 1 Cal. App. 2d 273, 36 P.2d 441 (1934); see Ames, A Reply to "Who Is a Vagrant in California?", 23 CALIF. L. Rev. 616, 618 (1935).

95. See Note, 59 YALE L.J. 1351, 1357 n.20 (1950), citing a report on interference with labor and civil liberties in Hudson County, N.J.

96. People v. Jackson (Super. Ct. San Francisco 1935) (unreported) ; see Comment, Who Is a Vagrant in Califormia?, 23 Calif. L. Rev. $507 \mathrm{nn} .2$ \& 3 (1935).

97. Brooks v. State, 33 Ala. App. 390, 34 So. $2 d 175$ (1948). There is little authority on how much of a continuendo is required to establish a vagrant mode of life. Compare Branch v. State, 73 Tex. Crim. 471, 165 S.W. 605 (1914) (conviction affirmed where police had watched defendant loaf and dance jigs for 13 days), with Blakeley v. State, $78 \mathrm{Ga}$. App. 516, 51 S.E.2d 598 (1949) (conviction reversed where police watched defendant loaf for 11 days).

98. This authority is generally assumed and is frequently explicitly provided by statute. E.g., N.J. REV. Stat. \$2A :169-3 (1951) ; ME. Rev. Stat. ANN. c. 137, § 37 (1954) (may arrest "upon view of" the offense); see PA. STAt. ANN. tit. 18, $\$ 2033$ (Purdon 1945). Where the power to arrest on sight is not statutory, it has been implied. People v. Formiscio, 39 N.Y.S.2d 149 (N.Y. City Ct. Spec. Sess. 1943).

99. People v. Craig, 152 Cal. 42, 46, 91 Pac. 997,999 (1907). 
No cases were observed in this study in which the police gave any indication of trying to get evidence on a defendant's mode of life and making an arrest only after they had observed a sufficient series of acts to add up to the prohibited status. Vagrancy is of use to the police in Philadelphia today as a weapon against suspicious persons only because the law is so loosely and illegally administered that an isolated act is all that is required for conviction. The magistrates were apparently unaware of the proof necessary to establish the status elements which are essential ingredients of the offense; in any event, they never applied them.

This emphasizes the absurdity of utilizing traditional vagrancy as a means of controlling persons suspected of serious criminality. Pauperism and vagrant status are not important indicia of the evils the police are primarily concerned with suppressing. Professional criminals are likely to have "visible means of support," and the attempt to prove they are vagrants runs into the difficulty described by a Chicago municipal court judge in discussing a vagrancy prosecution:

"In the Winkler case, if there ever was a case where there should have been a conviction, that was the case. They introduced machine guns and everything else, but the jury took the position, as they told one of the bailiffs afterwards, that a man who is a vagrant has no visible means of support, and how could he be a vagrant if he lives on Sheridan Road?" 100

A number of jurisdictions have tried to deal with this problem by enacting statutes whose elements are believed to be more reliable indicators of professional criminality. Such statutes have had constitutional difficulties as they have strayed from the traditional patterns whose common-law vintage makes them acceptable to the courts. ${ }^{101}$ One type of statute makes the key element the consorting of persons who have criminal reputations. ${ }^{102}$ So far these have been upheld by the courts, ${ }^{103}$ although they raise serious policy and constitutional problems. When compared with traditional vagrancy they have the advantage of making the elements of the offense reflect more reasonable grounds of suspicion under modern conditions than is provided by the status of poverty.

100. Testimony of Judge Thomas A. Green of Chicago Municipal Court, in Hearings Before a Subcommittee of the Senate Committee on Commerce, 73d Cong., $2 \mathrm{~d}$ Sess. 305, 308-09 (1934).

101. For decisions invalidating such statutes, see, e.g., Lanzetta v. New Jersey, 306 U.S. 451 (1939) ; People v. Belcastro, 356 I11. 144, 190 N.E. 301 (1934); People v. Licavoli, 264 Mich. 643, 250 N.W. 520 (1934); St. Louis v. Fitz, 53 Mo. 582 (1873).

102. E.g., N.J. Rev. Stat. § 2A:170-1 (1951); N.Y. Pen. LAw \$722(11). Illegal intent is also an element of such statutes, but typically this is unimportant because proof of the key elements is prima facie evidence of the required intent.

103. E.g., People v. Pieri, 269 N.Y. 315, 199 N.E. 495 (1936). 


\section{Catch-all of the Criminal Law}

The third major policy objective which is served by vagrancy law administration in Philadelphia has been almost completely ignored by courts and writers. When a magistrate talked about "cleaning up his district," he was referring to the role of vagrancy-type enforcement as the garbage pail of the criminal law. Prosecutions were carried on in a bewildering variety of other situations which had no relation to the suppression of criminality. These included cleaning "loafers" out of the city center, "mopping up" the drunkards in the skid row, punishing attempted suicides, obliging persons who desired to send unwanted aged relatives to the House of Correction on cooked-up vagrancy charges, convicting mentally ill persons of vagrancy and likewise confining them behind the House of Correction's bars, punishing minor nuisances which do not amount to any crime and vindicating affronts to police dignity. The common ground which brings such a motley assortment of human troubles before the magistrates in vagrancy-type proceedings is the procedural laxity which permits "conviction" for almost any kind of conduct and the existence of the House of Correction as an easy and convenient dumping-ground for problems that appear to have no other immediate solution.

\section{Dressing up the City Center}

These efforts were usually supported by editorials urging that: ". . . it is about time that these breathing spaces in the heart of the city be taken away from the idlers and the parolees and given back safely to the people." 104

During an earlier "blitz" it was reported that:

"[the effectiveness of the drive] . . . prompted the Central YMCA and other organizations yesterday to ask Captain Kronbar to widen the 'no man's land' for vagrants and rout them from other midcity loitering places." 105

At such times the tempo of activity in magistrates' courts increased, but unpublicized "clean-up" activity goes on continuously. None of the usual motivations of vagrancy apply to such action. There was apparently no suspicion of other criminality involved, and there was no attempt to force people to work. The only reason for the arrests was that the appearance of the victims was not attractive. 
Usually the evidence fell far short of that necessary to sustain vagrancy or habitual drunkenness, the offense in most instances being, as the newspapers report, no more than "idling and loitering." Pennsylvania has no statute outlawing loitering; indeed, most statutes which have sought to proscribe mere loitering have been held unconstitutional. ${ }^{106}$

\section{Cleaning Up the Skid Row}

The principal problem is drunkenness, but loitering is also involved. One magistrate described the clean-up process:

"About midnight on Saturday night the patrol wagons roll out with a group of officers on each. No call has come in for them; they know what they want. When they come to a certain block they stop, two officers go up one sidewalk and two on the other, and literally scoop them up."

A feature of these clean-ups are the "protective arrests" which occur when the officers find

"a better-dressed man, perhaps with a nice watch. He doesn't belong there. The police know only one thing can happen, so they pick him up, too, to protect him, charge him with vagrancy, and then the next morning the magistrate releases him, or after a few hours the house sergeant releases him on a Form $80 .{ }^{107}$ This helps the police, by saving them from having to look for the man who would have robbed him, and it helps the man by keeping him from being robbed."

This process goes on continuously. The drunk cell in a skid row police station is no sooner emptied by one morning's hearings than new arrests start coming in, grist for the following day's mill. Anyone familiar with skid row conditions will approach the problem of the police with understanding. One officer stated, "You find the same guy lying around night after night. Finally you get fed up, tip the magistrate off, and at least you know that you won't have to see his face for the next three months." Thus frequently, when a drunkenness defendant would be called up, a police officer would interject, "Judge, this man's in here all the time. He's a regular pest." The

106. Territory of Hawaii v. Anduha, 48 F.2d 171 (9th Cir. 1931); Commonwealth v. Carpenter, 325 Mass. 519, 91 N.E.2d 666 (1950); St. Louis v. Gloner, 210 Mo. 502 , 109 S.W. 30 (1908). But see State v. Jasmin, 105 Vt. 531, 535, 168 At1. 545, 546 (1933).

107. See note 162 infra. Compare this practice with Mass. ANs. Laws c. 272, $\S 46$ (1933), $\$ 45$ (Supp. 1954) ( $\$ 46$ provides for release of drunks "upon recovery" on condition that person so released waives any claim for damages which he might otherwise have had against arresting officer). 
magistrate would then impose sentence, and several times stressed to the writer the importance of such "cooperation" with the police. Many of these defendants were doubtless chronic alcoholics, and some may have been known as such to the magistrates on basis of personal observation, but in not one of the hearings observed was there competent evidence to sustain the charge of habitual drunkenness. ${ }^{108}$ The seriousness of alcoholism as a national problem and the complicated medical and emotional disorders which it presents dramatize the fact that radical changes are needed in procedures for handling the indigent alcoholic. The magistrates are completely unequipped to deal with the problem. $^{109}$

\section{Conviction of the Mentally or Physically Ill}

The use of a vagrancy conviction as a means of institutionalizing mentally ill persons was admitted to be illegal by magistrates interviewed but was defended as a necessary humanitarian service. The commitment of the physically ill is probably not intentional but is another by-product of procedural laxity. This abuse of the criminal process is best illustrated by abstracts from the medical records at the House of Correction:

A. G., vagrancy, 1/31/51. Had to be carried from the van by other prisoners, immediately transferred to Philadelphia General Hospital, where he died within 24 hours. The Medical Officer at Correction protested to the committing magistrate, who claimed that the defendant stood before him; the Medical Officer stated this would have been impossible.

H. Y., vagrancy, 2/5/51. Arrested at 4 P. M., he was taken to a hospital, treated for malnutrition, returned to the police station and committed the next morning. $\mathrm{He}$ arrived on a stretcher.

F. S., vagrancy, $2 / 14 / 51$. The defendant was taken to Philadelphia General Hospital by police. At 5:30 A. M. the hospital called police asking them to take him back. He was placed under arrest at 6:10 A. M. for being at the hospital "contrary to law" and was committed that morning. Arriving on a stretcher in serious

108. See note 11 supra. See Able v. State, 62 So. 2d 239 (Ala. App. 1953), reversing a conviction as a common drunkard where there was evidence of only six instances of drunkenness in a year, and imposing as a test that sobriety must be the exception; compare the following definition from the Pennsylvania Mental Health Act, PA. STAT. ANN. tit. 50, $\$ 1072$ (Purdon Supp. 1954): "(7) 'Inebriate' shall mean a person who is so habitually addicted to the use of alcoholic or other intoxicating or narcotic substances as to be unable or unwilling to stop the excessive use of such substances without help. The term shall include ... "habitual drunkard."

109. For alternative provisions for dealing with alcoholics, see the Mental Health Act, id. $\$ 1161$ (a) (3) (provision for voluntary admission of inebriate to mental institution); id. $\$ 1201$ (a) (6) (petition for court commitment). As the institution to which the patient is sent must approve, id. $\S 1203(\mathrm{e})$, and as institutional facilities are severely limited, the availability of this treatment is limited. 
condition, he was immediately transferred 10 miles back to Philadelphia General Hospital.

J. M., habit. drunk., 4/24/51. Arrived on a stretcher in restraints, answered all questions with whistles, previous mental hospital history.

T. S., vagrancy, $4 / 26 / 51$. On arrival at House of Correction, immediately transferred to Philadelphia General Hospital, diagnosis possible skull fracture.

H. B., habit. drunk., 5/26/51. Arrived in restraints.

A. K., habit. drunk., 5/28/51. Arrested at 9:30 P. M., at 2:30 A. M. taken to Philadelphia General Hospital, diagnosis alcoholism with suicidal intent. As no bed available, returned to station house, committed, arrived on stretcher.

S. G., vagrancy, 5/29/51. After trying to commit suicide in Reading Terminal, defendant taken by police to hospital, injury dressed, returned to station house and committed next morning. Immediately transferred to Philadelphia General Hospital because of loss of blood, suicidal tendencies.

F. M., habit. drunk., 6/28/51. Arrived on stretcher, semistuporous, died 7/1 in Philadelphia General Hospital. threats.

Y. H., habit. drunk., $7 / 10 / 51$. Arrived in restraints, suicide

P. W., vagrancy, $7 / 15 / 51$. Arrived on stretcher, immediately transferred to Philadelphia General Hospital in serious condition. In answer to protests, the magistrate admitted that the defendant, a Philadelphia resident, was in bad physical condition when before him, but stated that defendant's son was prosecutor and requested the commitment.

Similar cases were reported the following year during a study of the House of Correction by the National Probation and Parole Association, which observed that "it is unfortunate that so many psychotic or feebleminded inmates are held in the House of Correction for long periods." 110 These cases indicated attempts by the magistrates to find satisfactory solutions of problems for which they had neither the facilities nor the training to handle. The excuse that it was necessary to use a prison for cases of this kind because of the unavailability of other facilities may or may not have been valid. ${ }^{111}$ Even if it was,

110. Hiller \& Rector, Intake and Release Prochdures in the House of Correction, Philadelphia, PA. 11 (Nat'1 Probation \& Parole Ass'n 1953) (mimeo).

111. Compare the experience of Allegheny County, where the same necessity argument was advanced. When the County Board of Prison Inspectors ruled in October, 1953, that mental patients would no longer be accepted in jail, a temporary solution for the supposedly insoluble problem was found within two months. See JANAviTz \& BOzEman, Allegheny County Tackles a Mental Health Problem, Currents in Pennsylvania's Healti \& Wetfare 14, 16 (Pa. Citizen's Ass'n for Health \& Welfare, Summer 1954). 
it does not mitigate the fact that there was no justification for allowing a magistrate, untrained in medicine or law, to determine who should be committed in a summary, vagrancy-type criminal proceeding.

\section{Jail for the Aged}

An official at the House of Correction reported a case which typifies this problem. A private agency had been supporting a sixtyfour year old alien who was ineligible for relief but wished to get him into the Home for the Indigent until he was eligible for old age assistance. One of the agency's social workers was told by a magistrate that this could be done if she would bring her client before him. When this was done, he was immediately convicted as a vagrant and sentenced to three months. This brought him within. a stone's throw of his intended destination, as the House of Correction adjoins the Home for the Indigent on the same grounds; but the social worker was upset even though the magistrate assured her this was "the normal procedure." When the defendant found himself in a gloomy cell behind bars he became very agitated. A director's release and transfer to the Home for the Indigent were arranged. This is typical of the administrative rather than judicial correction of the more flagrant abuses. However, it leaves the defendant with a criminal record as a vagrant, which might have particularly serious consequences for an alien.

Other cases were observed in which daughters or wives of elderly men accused as habitual drunkards appeared to request commitment. The magistrates almost invariably complied and left the question of conviction up to the complainant. In some of these cases it appeared that this was the first time the defendant had ever appeared in court. Here again there may have been evidence which would have justified institutionalization in a home for the aged, but such evidence was not before the magistrates when they made their decisions. The result was a summary decision, based on one party's evidence without any social case work investigation of the circumstances, and a criminal conviction and prison confinement for a "crime" that at most was senility. ${ }^{112}$

Occasionally aged persons were picked up, convicted as vagrants and sent to the House of Correction where, for the first time, it was discovered that they had homes and that their relatives were engaged in a frantic search for them. ${ }^{113}$

112. For similar cases, see HILLER \& RECTOR, op. cit. supra note 110 , cases number $2,7,9,31$ and 44 .

113. Id. case number 14, in which a resident of Atlantic City who owned his own home and had a $\$ 2,000$ savings bank account was taken from a hospital to a magistrate who committed him as a vagrant at a time when his family was searching for him. 


\section{Self-Commitments}

A few cases were observed in which a defendant walked into the police station of his own accord and asked the magistrate to send him up. Such defendants were committed as vagrants. One case at the House of Correction was also observed. As the writer arrived in the morning, the guards were trying to get rid of an inmate who had just been discharged but who was sitting on the sidewalk just outside the entrance. Three hours later he was still sitting, this time 100 yards further down the sidewalk. Two mornings later he was observed arriving in the police van with a three month sentence as a vagrant.

A number of inmates appeared to be of this type, and some had as many as seventy prior commitments to the House of Correction. They were totally unable to take care of themselves, and as they advanced in age, they were transferred to the Home for the Indigent.

\section{Abating Nuisances}

Disputes within the confines of the home between a landlady and her boarder, between husband and wife or father and daughter, men who refused to pay for meals in restaurants, a man arrested because he entered a restaurant from which he had previously been ejected with orders never to return - these are examples of "annoyance" cases which illustrate the variety of magisterial practice. Usually this type of defendant was charged with disorderly conduct, which carries a maximum penalty of only a $\$ 10$ fine, or imprisonment up to 30 days in default of payment of the fine. ${ }^{114}$ Convictions were observed in all the foregoing cases, although probably none of the convictions would stand up on appeal. Such defendants were punished for nuisances which the complainant, the police, the magistrate and probably many of the public all agree should be punishable.

The most unusual instance of a vagrancy-type conviction being used to abate a nuisance involved a defendant who was convicted as an habitual drunkard, although he was not drunk when arrested and claimed that he did not drink. According to an oral report given to the House of Correction by the social worker of a private agency, the real reason for his commitment was that he was "oversexed." $\mathrm{He}$ allegedly requested intercourse with his wife three or four times a night, and neighbors who had overheard his requests testified against him. The social worker reported that he was committed for habitual drunkenness because "the magistrate couldn't think of anything else. 
What could he do? He had to send him away, he couldn't leave him there with that poor girl."

\section{Affronts to Police Dignity}

A problem related to the administration of vagrancy-type laws concerns arrests and prosecutions, usually for disorderly conduct but occasionally for vagrancy, which arise from altercations between the defendant and the police. Depending upon the character of the defendant, these cases may or may not fall within the scope of this study. ${ }^{115}$ Frequently disorderly conduct charges of this kind concerned "respectable" defendants; ${ }^{116}$ but in a number of instances alleged hostility between a police officer and the defendant was the ground upon which a vagrancy-type arrest was made.

Examples include a defendant described as a "tough guy" who was involved in a run-in with a police captain in plain clothes. Another was a defendant whom police testimony described as "known to be a cop-fighter," who was sitting in a bar making uncomplimentary comments about the police in general. When a plainclothesman who was present told him to stop, he became abusive and police used force to overcome him. A defendant of Mexican ancestry was found guilty for the use of abusive language to an officer who had ordered him to move out of the bus terminal. The defendant moved only from one side of the terminal to the other and talked back. As the defendant spoke Spanish, the officer did not understand what he said, but he assumed the words were abusive and made the arrest.

\section{Problems of Proof}

In a recent case a Washington publisher found he had only $15 \phi$ in his possession when his car stalled in Dover, Delaware. He went to the police station to phone his relatives for money, but while he was there his talk "just didn't ring right" to the police chief, "so we held him overnight on a vagrancy charge." The magistrate who heard the

115. Many of the disorderly conduct cases observed are not reported in this study because they are irrelevant to the general problems of vagrancy-type law, e.g., street fights, disturbances in taprooms, boisterous activity in public places. We are concerned with disorderly conduct, however, where it is applied as a vehicle for prosecuting vagrancy-type defendants or to punish by analogy conduct which is not specifically proscribed by statute but is objectionable to police or magistrates.

116. E.g., a case in which a defendant charged with disorderly conduct tore up a parking ticket in front of the officer who had just handed it to him and allegedly cursed the officer. Compare Taylor v. Olschafsky, 35 Delaware County Rep. 393, 395 (Delaware County, Pa., C.P. 1947) (upholding damages for false arrest where, in argument over traffic ticket, the officer "lost his head and, in a police officer, this is not good"), zith Commonwealth v. Savko, 34 Erie County Rep. 77 (Erie County, Pa., Q.S. 1951) (upholding conviction of disorderly conduct on similar facts). 
case next day said that the defendant "rambled" and "if he hadn't been so belligerent . . . he could have been released right away." So the defendant spent another twenty-four hours in jail until his relatives persuaded the magistrate that the defendant was in fact the respectable citizen he claimed to be. The magistrate explained, "We didn't want to let the man loose in society without being very sure of his background." 117

This case epitomizes the manner in which the burden of proof was allocated in Philadelphia practice observed in this study. As a practical matter in many of the cases, the defendant is prima facie guilty, and the burden is placed upon him to give a satisfactory answer to the question, "What have you got to say for yourself?" Despite the "overriding presumption of innocence," 118 vagrancy statutes are so drafted that to a limited extent this magisterial practice can be justified under the law.

On its face the Pennsylvania vagrancy statute requires that five facts must be found before a valid conviction can be returned. ${ }^{119}$ The defendant must

(1) have come from outside the state, and

(2) be found loitering or residing therein, and

(3) follow no labor, trade, occupation or business, and

(4) have no visible means of subsistence, and

(5) be unable to give a reasonable account of himself or his business in the place where he is found.

The first two requirements raise no unusual procedural problems. On its face the third element would appear to be part of the proof which the prosecution must supply, but although the cases are often strangely silent on the point, the indication is that this element creates an implied burden on the defendant to prove that he has employment or has made efforts to obtain it. The fourth element also creates an implied presumption which must be rebutted by the defendant. Although the statute purports to say that, in combination with the other elements, lack of visible means of support is punishable, ${ }^{120}$ this construction would lead to ridiculous results where the defendant, although apparently without means of support, in fact could prove that he had sufficient re-

117. Wilmington (Del.) Morning News, June 21, 1955, p. 1, col. 3.

118. Morissette v. United States, 342 U.S. 246, 275 (1952).

119. PA. Stat. ANN. tit. 18, §2032 (IV) (Purdon 1945).

120. An argument that the statute should be given this literal interpretation will be found in Gentry v. Town of Booneville, 199 Miss. 1, 5, 24 So. 2d 88, 89-90 (1945) (concurring opinion of Smith, C.J.). 
sources. It is clear from the cases that proof of no visible means of subsistence merely creates a prima facie case which the defendant can rebut by showing actual lawful means of support. ${ }^{121}$ The fifth element clearly places a burden on the defendant; once guilty appearances have been shown, he must rebut the prima facie case by giving a "reasonable account of himself." Thus once it has been shown that a person who has come from without the state has been found loitering, some burden must be assumed by the defendant if he is to show his innocence.

As there are no relevant Pennsylvania cases, an analysis of the nature of these burdens requires examination of analogous provisions in other jurisdictions. A few vagrancy statutes provide for the allocation of the burden of persuasion, such as a provision that proof of idleness and other appearances of guilt ". . . shall constitute a prima facie presumption that such person is a vagrant, . . ." ${ }^{122}$ or mean that ". . . the burden of proof shall be upon the defendant to show that he has sufficient property from which to obtain a support, or suffcient means of maintaining a fair, honest, and reputable livelihood. "123 A showing of idleness may place upon the defendant the burden ". . . to show reasonable efforts in good faith to secure employment, . . ." ${ }^{124}$ and the legislative history of the District of Columbia vagrancy statute shows the congressional intent ". . . that the burden shall be upon the defendant arrested under this legislation to show that he has a lawful employment or has lawful means of support realized from a lawful occupation or source." ${ }^{125}$ Without such legislative aid the courts have reached the same result, that ". . . the State has made out its case when these appearances of guilty violation are proven." 126

A few courts have held that the "prima facie case" made out by such a showing of guilty appearances bursts in the face of uncontradicted rebuttal testimony, and that unless the state then proceeds with additional evidence, a conviction will be reversed. ${ }^{127}$ But in most jurisdictions the burden upon the defendant is the burden of persuasion; ${ }^{128}$

121. See note 120 supra, and notes 126,127 infra.

122. S.D. CODE $\$ 13.1424$ (1939).

123. Ala. Code Ann. tit. 14, § 439 (1940).

124. Iowa CoDE $\$ 746.2$ (1950); see also VA. CODE ANN. §63-339 (1950).

125. H.R. REP. No. 1248, 77th Cong., 1st Sess. (1941).

126. Hutchins v. State, 172 Tenn. 108, 112, 110 S.W.2d 319, 321 (1937).

127. Blakeley v. State, 78 Ga. App. 516, 51 S.E.2d 598 (1949); State v. Oldham, 224 N.C. 415, 30 S.E.2d 318 (1944); cf., State v. Hagen, 130 S.W.2d 250, 252 (Mo. App. 1939); People v. Sohn, 269 N.Y. 330, 335, 199 N.E. 501, 503 (1936).

128. See, e.g., Wallace v. State, 16 Ala. App. 85, 75 So. 633 (1917) ; Burns v. District of Columbia, 34 A.2d 714 (D.C. Munic. App. 1943); State v. Hall, 25 N.J. Misc. 381 (Essex County Ct. Spec. Sess. 1947); City of Greenville v. Ward, 94 S.C. 321, 77 S.E. 1021 (1913). 
thus the jury ". . . will not be bound to accept in satisfaction the unsupported statement of the accused although no witness is produced who is able to testify directly to the contrary-this because to hold otherwise would, in many cases, put it in the power of the accused, by his own unsupported assertions, to nullify the statute, and render it of no use." ${ }^{229}$ The defendant's income, if not apparent, is ". . . peculiarly within his knowledge and power to bring forward and establish. . . . If he had an employer he might have produced him, or fellow employees; if he had a bank account he might have produced his banker." ${ }^{130}$ On this theory a District of Columbia pickpocketvagrancy conviction was sustained although the defendant gave a plausible and unrebutted explanation of the $\$ 65$ found on his person. ${ }^{131}$

The burden of rebuttal which the courts have thus placed upon the defendant is magnified by the vagueness of the statutory elements. If the defendant wishes to show that he has "visible means of support" and thereby challenge the basic fact on which rests the presumption of no actual means of support, he will find no guidance in Pennsylvania and little in other jurisdictions. Some courts state, without elaboration, that this is "a term well understood" and with "a definite and fixed meaning." 132 Others have stated that, although "difficult of precise definition or measurement," 133 its "long usage" has "fixed" its significance and directed it against the man ". . . who hangs about streets and public places without . . . visible means of support. " 134 Under the parent British law a penny in the pocket may be sufficient; ${ }^{135}$ thus when a woman arrested for vagrancy was found on examination to possess 9 shillings 6 pence, the magistrate ". . . had no option but to discharge her." 136 In this country the few decisions range from those following the British rule to cases excluding as irrelevant evidence the fact that the defendant had money on his person at the time of arrest. ${ }^{137}$ It is unknown what the law is on this point in Pennsylvania; ${ }^{138}$ in the few cases which were observed where the police

129. Gentry v. Town of Boonville, 199 Miss. 1, 5, 24 So. 2d 88, 89 (1945).

130. Hutchins v. State, 172 Tenn. 108, 111, 110 S.W.2d 319, 321 (1937).

131. Burns v. District of Columbia, 34 A.2d 714 (D.C. Munic. App. 1943).

132. Ex parte Taft, 284 Mo. 531, 544, 225 S.W. 457,461 (1920).

133. People v. Johnaken, 196 Misc. 1059, 1061, 94 N.Y.S.2d 102, 104 (New Rochelle City Ct. 1950).

134. People v. Sohn, 269 N.Y. 330, 334-35, 199 N.E. 501, 502 (1936).

135. Departmental Commitree on Vagrancy, Report (London 1906).

136. See 95 JUST. P. 267 (1931).

137. Branch v. State, 73 Tex. Crim. 471, 165 S.W. 605 (1914). Money in the pocket may be regarded as no proof because of the "danger" that vagrants will carry money as a subterfuge to avoid arrest. People v. Cramer, 139 Misc. 545, 547, 247 N.Y. Supp. 821, 824 (N.Y. City Ct. Spec. Sess. 1930).

138. Similarly if the defendant wishes to rebut the presumed fact by showing that he has actual means of support, there is no case authority to guide the courts in deter- 
records showed that the defendant had a considerable sum of money on his person when arrested, the problem was resolved by convicting the defendant so rapidly that he had no chance to raise the defense.

The Pennsylvania statute makes one element of the crime the fact that the accused has no employment. Suppose he is physically unfit or is unemployed and cannot find a job? It has been suggested that ". . . he may be convicted and imprisoned, whether such condition is his misfortune or his fault." 139 Such an interpretation of the statute would unquestionably be rejected today, and it would be a good defense if the defendant could show "good faith" or "due diligence" or "reasonable effort" to obtain employment. ${ }^{140}$ We have already seen that the defendant's unsupported testimony may not be credited by the trier of fact and thus may not be sufficient to rebut the prima facie evidence. Must he produce copies of his employment applications or bring into court to testify on his behalf the men who have refused to employ him? An early English statute made it a violation if a man refused an offer to work "for meate and drynke" alone if nothing better could be obtained. ${ }^{141}$ American statutes imply that if the basic fact of idleness is to be rebutted, a defendant must not refuse any offer of work, no matter what the wages, working conditions or choice of employment. ${ }^{142}$

The vagueness of the statutory elements and the difficulties of making the rebuttals which the courts have required raise serious constitutional problems which are beyond the scope of this Article. ${ }^{143}$ At

mining what amount of money is required. One court has required that a defendant have enough "to support himself reasonably." People v. Cramer, supra note 137, at 825. To the obvious questions, "for how long, and by what standard of living?" there is no answer.

139. In the Matter of Forbes, 11 Abb. Prac. 52, 55 (N.Y. Sup. Ct. 1860).

140. Cf. Ex parte Taft, 284 Mo. 531, 545, 225 S.W. 457, 461 (1920), where the ordinance in question required one charged with vagrancy to show "reasonable effort and in good faith" to secure work to rebut a prima facie case. The court held that this was too vague because "each trial tribunal would be making its own ordinance" as to what "amounted to 'reasonable effort."

141. 1 EDw. 6, c. 3 (1547).

142. The only exceptions found are Kan. GeN. Stat. ANN. \$21-2409 (1949) (violation to refuse to work only "when work at fair wages is to be procured in the community"), and VA. CODE ANN. §63-338(2) (1949) (punishes only those who "refuse to work for the usual and common wages given to other laborers in like work in the place where they then are").

143. In Mobile, J. \& K.C.R.R. v. Turnipseed, 219 U.S. 35, 43 (1910), the only requirement was that there be "some" rational connection between the fact proved and ultimate fact presumed. But Turnipseed was a civil case, and it is doubtful if that rule is correct for criminal cases. It was not even applied in the peonage cases, Bailey $v$. Alabama, 219 U.S. 219 (1911), and Taylor v. Georgia, 315 U.S. 25 (1942), and in other cases where the Court purported to find an insufficient rational connection it appears that other factors actually motivated the decisions, e.g., unfairness to the defendant in Manley v. Georgia, 279 U.S. 1 (1929), and Tot v. United States, 319 U.S. 463 (1943). More useful is Justice Cardozo's examination of the basic fact to see if it carries "a hint of criminality." "For a transfer of the burden, experience must teach that the evidence held to be inculpatory has at least a sinister significance." Morrison v. California, 291 U.S. 82, 90 (1934). This test was the one applied in that case and the peonage 
the practical level in Philadelphia, it is clear that most defendants could not possibly meet such a burden of rebuttal. Although a statute applicable to Philadelphia requires that "all persons arrested shall be given the opportunity to communicate promptly with, be interviewed or examined by, such persons as they desire . . .," 144 some defendants alleged that they were denied this right following their arrest, and such denials may be common. ${ }^{145}$ Even if unrestricted access to the telephone were provided, it would be difficult for a man arrested during the night to marshal the witnesses he needs to carry his burden of proof and have them assembled ready to testify when court convenes at 9 a.m.

Frequently defendants were not permitted to make any rebuttal, being cut off with some such remark as "nothing you say will help," or if rebuttal was permitted, the magistrate indicated that he had already prejudged the case, making remarks such as these: self?"

"You're a bum. Well, what have you got to say for yourthere?"

"What do you do for a living? Steal a little here and a little

In one case a defendant was charged with disorderly conduct. The complaining witnesses were his ex-girl-friend and her sister, who alleged that he had annoyed them and created a disorderly scene in their home. After an impassioned description of these activities, one of the girls stated that this sort of thing could not go on much longer.

"Well, you won't have to worry about it for the next three months," said the magistrate. He turned to the defendant for the first time and said, in rapid-fire succession: "Well, what have yuu got to say for yourself? Why did you do it? Three months in the House of Correction."

On the evidence presented, this defendant probably had a valid defense to the charge of disorderly conduct for which he was ostensibly on trial, i.e., that the disturbance alleged against him was not in public. But as the sentence imposed upon him was greatly in excess of the

cases, and is implied in Casey v. United States, 276 U.S. 413 (1928) (proof that defendant had possession of narcotics creates immediate suspicion of criminality and presumption therefore valid); Yee Hem v. United States, 268 U.S. 178 (1925) (same as to opium); and in the cases cited and distinguished in Tot v. United States, supra. By this standard the presumptions implicit in a vagrancy prosecution would fall. "The mere state of being without funds is a neutral fact-constitutionally an irrelevance, like race, creed, or color." Edwards v. California, 314 U.S. 160, 185 (1941) (concurring opinion of Jackson, J.). This reasoning would apply to the vagrancy presumptions with even more force, for the basic fact which the state must prove is merely that the defendant apparently has no job and means of livelihood.

144. PA. Srat. ANN. tit. 42, §1113 (Purdon Supp. 1954).

145. See also Note, Compelling Appearance in Court: Administration of Bail in Philadelphia, 102 U. PA. L. REv. 1031, 1054-55 (1954). 
maximum for disorderly conduct, it is apparent that he was convicted of either habitual drunkeness or vagrancy, although there was no evidence relating to either charge.

\section{Summary Procedure}

Like the substantive law, the practice of making vagrancy summarily triable before a magistrate originated early in the fifteenth century in the aftermath of the Black Death and feudalism. ${ }^{146}$ This procedure was carried over to the colonies, and, by mechanical application of the rule that limited jury trial to cases for which it existed when the constitution was adopted, it was held that vagrancy-type offenses were summarily triable. ${ }^{147}$ Yet a magistrate in a vagrancy case can impose up to one year's imprisonment for the first offense and two years for certain repeaters. In no other category of criminality does Pennsylvania impose so severe a sanction without the right to trial by jury. Some offenses classified as misdemeanors have a lesser sanction than vagrancy, ${ }^{148}$ and all other Pennsylvania summary offenses provide for imprisonment only in default of payment of a fine, and then only for 30 days or less. ${ }^{149}$

This denial of jury trial has been rationalized on the grounds that it saves expense to the state and benefits the defendant by avoiding oppressive delay. ${ }^{150}$ It is maintained that the defendant is not deprived of any substantial rights, because the summary proceeding must still satisfy due process requirements of a fair hearing. ${ }^{151}$ Beyond this, because it is in derogation of the right to jury trial, English writers have taken a "strict view" of summary procedure, ${ }^{152}$ a view applied in Pennsylvania. ${ }^{153}$ At its minimum the fair hearing required would include the opportunity for the defendant to know and plead to the charge against him, that the case against him be by competent evidence, that he have

146. 2 Hen. 5 , c. 4 (1414).

147. Byers \& Davis v. Commonwealth, $42 \mathrm{~Pa} .89$ (1862).

148. See PA. Stat. ANN. tit. 18, $\$ 4511$ (Purdon 1945) (keeping disorderly house), id. $\$ 4512$ (prostitution), id. $\$ 4519$ (public indecency) and id. $\$ 4524$ (obscene literature) for offenses classified as misdemeanors with trial by jury but with a maximum penalty of one year, less than vagrancy.

149. E.g., id. $\$ 4406$ (disorderly conduct, $\$ 10$ or 30 days in default); $i d$. $\$ 4699.4$ (worldly employment on Sunday, $\$ 4$ or 6 days in default).

150. State v. Glenn, 54 Md. 572, 605 (1880); 4 STEPhen, ComMrantaries on THE Laws of ENGLAND 265 (15th ed. 1908) (summary procedure is "designed for the greater ease of the subject, by doing the offender speedy justice, and by not harassing jurymen with frequent attendances to try every minute offence").

151. See, e.g., Palko v. Connecticut, 302 U.S. 319, 327 (1937) : "The hearing, moreover, must be a real one, not a sham."

152. E.g., 4 Blackstone, Commentaries *280-81.

153. Commonwealth v. Borden, $61 \mathrm{~Pa} .272$ (1869). 
adequate opportunity to make a defense and that there be a record made so that judicial review is possible. ${ }^{154}$

The failure to meet these requirements in all observed cases would suggest that, while undue delay may be oppressive, a procedure that moves so rapidly that a defendant cannot prepare a defense is perhaps even worse. The following conclusions about the way in which summary procedure was administered in the observed cases shows how Philadelphia practice in vagrancy-type prosecutions deprived defendants of the most elementary requirements of a fair hearing.

(1) Defendants were rarely informed of the charge against them until the "trial" was completed, and in only one or two instances were they asked to plead guilty or not guilty.

(2) There was no pretense of proving the crime charged with competent evidence and, with only one exception, ${ }^{155}$ there were no competent witnesses for the prosecution. Usually the only testimony was the hearsay statement of a police officer not present at the arrest, who reported to the magistrate what the police records said about the case. Even this was dispensed with in many cases.

The proof in most cases consisted of the mere exhibition of a "bum," with the result that there should have been an acquittal in almost every case. Thus there was no evidence of habitualness in any habitual drunkenness prosecution observed, unless the magistrate's unsubstantiated memory and/or opinion or a policeman's unsworn comments be so considered; and in many vagrancy cases, despite undisputed testimony that the defendants were Pennsylvania residents, convictions were found under a statute that applies only to those who come from "without this Commonwealth."

This suggests that perhaps the primary importance of the right to a jury trial is that it militates, to some degree, against sham hearings.

(3) Defendants were uncounselled and unaided. While lawyers appeared in a few disorderly conduct cases, in not one observed vagrancy or habitual drunkenness prosecution was the defendant represented by counsel. The Voluntary Defender was not present; and the District Attorney plays no part in these prosecutions.

154. For other Pennsylvania citations see, Binns, Justice 883-87 (12th ed. 1928). Compare State v. Labato, 7 N.J. 137, 150-51, 80 A.2d 617, 623 (1951), to the effect that vagrancy-like crimes are "minor offenses denounced by statute below the grade of misdemeanors, and therefore punishable in a summary manner, yet quasi-criminal in essence and subject to the procedural rules governing criminal prosecutions."

155. In this case, a defendant was apparently charged with panhandling, and although his examination showed him to be within the broad magisterial definition of vagrancy, the particular magistrate sitting that day discharged him because the prosecution witness failed to appear. This was the only vagrancy case observed in which there was any reference to prosecution witnesses. 
(4) All other irregularities were accentuated by the speed of $\mathrm{jt}-$ dicial process, referring both to the rapidity with which the "trials" themselves are dispatched ${ }^{156}$ and the short interval between arrest and final disposition. A man arrested during the night had usually been tried, convicted and was en route to the House of Correction by eleven in the morning. We have noted that this minimizes the opportunity to retain a lawyer, contact friends or prepare a defense, even assuming defendants are allowed to contact anyone.

(5) No records were kept which are available to magistrates at time of trial to show prior convictions, although the frequency of intoxication arrests is obviously a relevant factor in a determination of whether a defendant is an habitual drunkard. Further, the House of Correction Act rigidly conditions the sentence which a magistrate can lawfully impose upon the number of prior commitments, ${ }^{157}$ but this requirement is ignored. At least one magistrate seemed to feel no need for such records, on numerous occasions telling defendants: "All right, don't let me see you here again. I never forget a face. I may not remember your name, but I never forget a face."

(6) In the overwhelming majority of cases, the magistrate's court is also in practice the court of last resort. The careful provisions for appeal, certiorari and habeas corpus, ${ }^{158}$ which on the statute books look so fair, are almost a dead letter as far as these defendants are concerned. ${ }^{159}$ Thus there is given ". . . to the magistrate in [vagrancy law] . . . an almost unchecked opportunity for arbitrary oppression or careless cruelty." 160 The few figures available in other jurisdictions show a similar rarity of appeal. ${ }^{101}$

(7) Summary procedure suffers from the absence of the pretrial procedure, which in felony or misdemeanor cases operates to weed out

156. See text at pp. 605-06 supra. One magistrate has described sitting over a weekend and disposing of 66 prisoners in 3 hours on Saturday and 100 in 4 hours on Sunday. Gilbert, Our Magistrate's Courts, 6 THE SHINGLE 68, 71 (1943).

157. Pa. Star. Ann. tit. 61, $\$ 681$ (Purdon 1930).

158. For discussion of these three methods and the distinctions between them in Philadelphia practice, see CrIMres SuRvey Comm. of THE LAw ASs'N OF PHILADELPHIA, REPORT 302-09 (1926). All of these methods of review require allowance by the reviewing court, and there is no appeal as of right.

159. The magistrate who in 1951 was handling the largest number of vagrancy cases informed the writer at that time that he could recall "only two appeals in the last six years." At the same time, the clerk of the Philadelphia Quarter Sessions Court could not recall a single vagrancy appeal.

160. In the Matter of Forbes, 11 Abb. Prac. 52, 55 (N.Y. Sup. Ct. 1860).

161. A few studies show less than 1\% appeals. See Note, 59 Y ALE L.J. 1351, 1357 n.21 (1950). Appeal figures for New York City were found for two years, and showed that for vagrancy other than prostitution in 1930 and 1931 , there were 3,359 convictions and 1 appeal. City Magistrate's CoURTs, New York City, ANN. Rep. 20, 56 (1930); id. at 38 (1931). 
defendants who are innocent or against whom there is insufficient evidence. Such defendants pass through numerous checks: preliminary examination, indictment or information, and preparation of the case leading, perhaps, to a nolle prosequi. All these involve correctives for police errors or abuse, and many cases in practice are dropped at these various levels. The only pretrial procedure in a vagrancy-type case is that of the police house sergeant, who, in perhaps 10 per cent of the drunk arrests, releases the defendant without any appearance before a magistrate. ${ }^{162}$ Thus the presumption of innocence has much more probative validity in a magistrate's court because of the absence of pretrial discretion, but, paradoxically, it is given much less weight than in the Court of Quarter Sessions.

(8) The background and lack of legal training of most of the magistrates is an important factor. As no other lawyers participate in the proceedings, a magistrate who himself is probably untrained in law must administer technically difficult vagrancy laws. This is not the place to assess the magisterial system as a whole, or to review the arguments for and against a lay judiciary. ${ }^{163}$ The principal reason advanced for having "local community courts" presided over by a lay judiciary is that this will prevent the development of "a legal formalism." ${ }^{164}$ Whether or not such informality is desirable in minor civil controversies, ${ }^{165}$ it is precisely the lack of any "legal formalism"

162. Under this procedure, when persons whom the police described as respectable were arrested for drunkenness, they were permitted to telephone relatives to come get them. Form 80 of the police department was executed, as follows: "I,..... do hereby accept the responsibility of safely escorting to his home ...... who has been taken into custody on.$\ldots \ldots$ at $\ldots \ldots$ for his own protection because of intoxication. $M y$ relation to him is ......." In the 6th Police District in June, 1951, out of 850 drunkenness arrests, there were 81 discharges on Form 80 . This practice is probably illegal. See Note, 59 Yale L. J. 1351,1359 n.28 (1950); Doherty v. Shea, 320 Mass. 173, 68 N.E.2d 707 (1946). But the form might be construed as a waiver of any claims for damages for false imprisonment. Cf. MAss. ANN. LAws c. 272, \$\$ 45-46 (Supp. 1954).

163. Compare Ervin, The Magistrates' Courts of Philadelphia 108-15 (1931) (stressing the necessity of legal training for the discharge of magisterial duties), with COMMISSION APPOINTED AT THE RECOM MENDATION OF THE SPECIAL GRAND JURY OF 1935 To Study and Recommend Improvements in the Laws Relating to Magisstrates and Magistrates' Courts in the City of Philadelphia, Report. The Commission supported the concept of "local community courts" and reiected proposals which would have required that magistrates be members of the bar. The reasoning of the Commission was directed wholly at civil suitors who "have no clear conception of the legal aspects of their problems .... Their need is less for a determination of their technical legal rights, than for a wise adjustment of their difficulties with their neighbors and others."

164. Ibid.

165. No study has ever been made examining magisterial practices in their civil jurisdiction, and how the Commission, supra note 163 , was able to reach the conclusions it did in the absence of such evidence is not clear from its report. It would certainly seem to be no solution for the problem of untrained and unrepresented litigants to provide that the judge shall be untrained as well. For a study revealing magisterial inadequacy and abuse in another aspect of their jurisdiction-admission to bail, see Note, Compelling Appearance in Court: Administration of Bail in Philadelphia, 102 U. PA. L. REV. 1031, 1036-46 (1954). 
which is the primary cause of much of the abuse in vagrancy-type cases. Informality is a dubious goal for proceedings whose outcome may be a sentence of imprisonment of up to two years.

(9) As has been noted, the magistrate is crippled by the lack of any of the treatment tools developed by modern criminology. He cannot grant a suspended sentence which includes supervised probation, or commit the obviously ill to a medical institution, or obtain any of the information essential to intelligent disposition of the cases. There is neither the time nor the facilities for obtaining pre-sentence reports or checking with other social agencies for information about the defendants. One woman defendant found walking the streets stated that she had no family and no friends in Philadelphia and lived in rooming houses with temporary work as a typist. She appeared to be mentally ill, and the magistrate was obviously trying to make a more constructive disposition of her case than sentencing her to the House of Correction. He finally discharged her and sent her to the YWCA in a $\mathrm{cab}$, but he had no means of insuring that she would get attention or even that she would go there. A complete gulf separates the magistrates' courts from constructive welfare and treatment facilities.

The explanation of the tolerance by bar and public of such abuse of elementary procedural rights is rooted in one fact: most of the defendants are drawn from skid row-drunks, idlers, loungers, suspected petty criminals, beggars, bench-sleepers. Perhaps most are chronic alcoholics, often incapable of aiding themselves, and many are transients in a strange city. Economically most are at or near the level of poverty. Many persons interviewed during this study summed up this attitude and explained their lack of concern with what the police and magistrates do by the label they attached to the entire group: "Bums."

\section{Conclusion}

Some of the abuses which have been outlined can be met by reforms such as (1) extension of the Voluntary Defender system to the magistrates' courts, which would not only provide legal aid where it is urgently needed but would result in an immediate raising of the level of procedural fairness in vagrancy-type proceedings; (2) transfer of jurisdiction over vagrancy-type offenses to the Municipal Court to achieve essential centralization in the handling of the cases and to provide the necessary probation, social service and psychiatric diagnostic and treatment services; (3) development and utilization of other treatment possibilities for indigent alcoholics, with commitment to the House of Correction reserved for use only as a last resort if no other treatment program can be developed. 
Beyond such immediate procedural and treatment reforms, however, is the need for re-examination of the whole vagrancy policy of our law. Little can be said in support of the use of vagrancy-type statutes to repress alcoholism, for the recidivism of the confirmed "habitual drunkard" shows that short prison sentences are wholly ineffective as a means of treating what is essentially a medical problem. ${ }^{186}$ Nor is there any legal or policy justification for imprisoning people because their poverty or characterization as "bums" makes them vaguely undesirable. The use of vagrancy sanctions to deter such persons from entering Philadelphia and to banish them if they do come is unconstitutional and indefensible. The only reason such administration is tolerated is because the defendants involved are too poor or too weak to assert their obvious rights.

If vagrancy-law administration in Philadelphia involves any socially desirable policy, therefore, it is because its flexibility gives the police a residual discretionary power to control suspicious persons or harass suspected professional criminals. This is an illusory advantage, for the substitution of harassment for the more difficult job of obtaining the evidence necessary to convict criminals of the substantive offenses of which they are guilty encourages superficial and inefficient police work. ${ }^{107}$ If the suspect is actually a professional criminal, harassment with a three months vagrancy sentence serves neither the incapacitative nor the deterrent end of the criminal law. ${ }^{168}$ At most it

166. An example of the recidivism is given at p. 627 supra. Of 5166 inmates committed to the House of Correction in $1950,40 \%$ had prior commitments to that institution; $6.3 \%$ had more than ten prior commitments; and $1.4 \%$ more than 30 commitments. PHilladelphia House of Correction, ANN. Rep. 50 (1950). Of the cases studied by HILLER \& RECTOR, op. cit. supra note 110, many involved repeated recidivism. Compare the report on a 51 year old Seattle alcoholic, who in a 25 year period was arrested 223 times and spent 11 years and 143 days in Seattle City Jail on short sentences for drunkenness. Seattle Times, Oct. 17, 1946, p. 10, col. 1. See also New York Times, Jan. 26, 1953, p. 14, col. 1 (Brooklyn man arrested 103 times for intoxication and vagrancy since 1925). The cost of such treatment is staggering. In Philadelphia County alone, 1430 vagrants and 1645 habitual drunkards were committed in 1950, at a cost of over $\$ 400,000$ for House of Correction maintenance alone. Figure compiled from PHILAdELPHIA House OF CORRECTION, ANN. Rep. (1950), on the basis of an average stay of 58 days per inmate at $\$ 2.34$ a day. To this must be added the combined value of police services diverted from more important tasks to handle this multitude of cases.

167. "The underlying purpose [of public enemy vagrancy laws] is to relieve the police of the necessity of proving that criminals have committed or are planning to commit specific crimes." N.Y. LAW REvision Commission, REPORT 591 (1935).

168. Under an Illinois reputation-vagrancy law, “. . we have harassed and convicted otherwise immune gangsters, kidnapers, gunmen, thugs and racketeers in the persons of Maxie Eisen, 'Machine Gunner' Jack McGurn, 'King of the Bomb Throwers' James Belcastro, 'Two Gun' Louie Alterie, and numerous mad dogs of the west side. ..." Testimony of Thomas A. Green, in Hearings, supra note 100, at 307. This campaign was short-lived, however, as the statute was declared unconstitutional. People v. Belcastro, 356 I11. 144, 190 N.E. 301 (1934). As the maximum penalty was six months, it seems doubtful that such a conviction is much of a solution to the problem posed by a man called "King of the Bomb Throwers." 
may drive a few criminals into another jurisdiction without any net improvement in the control of crime. If the defendant is suspected merely because of his past criminal record, vagrancy-type harassment, like criminal registration ordinances, ${ }^{169}$ impedes the rehabilitative end of the criminal law by closing ". . . the doors to reformation, repentence or a new try at life." 170 In fact vagrancy laws of the Pennsylvania type can never be an effective harassment device, for their utility depends upon illegal administration, and the illegality means that any professional criminal with funds at his disposal can gain a speedy release by retaining an attorney to bring habeas corpus. ${ }^{171}$ Thus only the paupers and the helpless can be harassed with vagrancy-type commitments to the House of Correction.

Nor is harassment either a necessary or a desirable method of deterring professional criminality. Probationary control over a defendant who has once been convicted offers a more equitable and effective means of supervising persons suspect because of past criminality. Requiring such a probationer to report on his employment, his income and his net worth at periodic intervals would be a far more efficient deterrent against a return to criminality than to permit the police to arrest him at will for consorting or other vaguely suspicious activities.

One cannot escape the conclusion that the administration of vagrancy-type laws serves as an escape hatch to avoid the rigidity imposed by real or imagined defects in criminal law and procedure. To the extent that such rigidity presents a real problem and that the need for a safety valve is not merely the product of inefficiency on the part of police or prosecutors, such a problem should not be dealt with by indirection. If it is necessary to ease the prosecution's burden of proof or to legalize arrests for mere suspicion, then the grave policy and constitutional problems posed by such suggestions should be faced. If present restrictions on the laws of attempts or arrest place too onerous a burden upon the police because of the nature of modern crime, then such propositions should be discussed and resolved on their merits, as, for example, the proposals in the Uniform Arrest Act. ${ }^{172}$

The economic purposes which once gave vagrancy a function no longer exist, and the philosophy and practices of welfare agencies have

169. See Note, Criminal Registration Ordinances: Police Control of Potential Recidivists, 103 U. PA. L. Rev. 60 (1954).

170. People v. Pieri, 269 N.Y. 315, 327, 199 N.E. 495, 499 (1936).

171. An example was revealed during the hearings of the Kefauver Committee in which Samuel Hoffman, a Philadelphian with a long criminal record, was arrested as he got off the train at 30th Street Station and immediately sentenced to a year as a vagrant. He retained an attorney and was promptly released on habeas corpus. Philadelphia Evening Bulletin, March 6, 1951, p. 31, col. 7.

172. Warner, The Uniform Arrest Act, 28 VA. L. REv. 315, 343-47 (1942). 
so changed relief methods that a criminal sanction to enforce an Elizabethan poor law concept is outdated. To try to utilize a feudal statute as a weapon against modern crime and as a means of liberalizing the restrictions of criminal law and procedure is both inefficient and an invitation to the kind of abuses which this study has shown to be widespread.

It was to avoid just such abuses that the restrictions of our criminal procedure were developed. If the administrative flexibility gained by the circumvention of that procedure in vagrancy-type cases has resulted in a return of those abuses, perhaps that more than anything else demonstrates the wisdom of our traditional procedural protections. 